\title{
Chapter 8 \\ Different Omics Approaches in Cereals and \\ Their Possible Implications for Developing \\ a System Biology Approach to Study the Mechanism of Abiotic Stress Tolerance
}

\author{
Palakolanu Sudhakar Reddy and Nese Sreenivasulu
}

\subsection{Introduction}

Cereals comprise a number of crops including rice, wheat, maize, barley, rye and sorghum. In the form of starch and proteins, the cereal grains provide nearly $60 \%$ of the calories consumed globally as food and fodder. There is a growing challenge to meet the global demand of food security for a human population of 9 billion expected by the year 2050 (Royal 2009; Sreenivasulu and Schnurbusch 2012). Current predicted climatic conditions such as prolonged drought and heat episodes pose a serious threat for the agricultural production world-wide, affecting yield losses estimated at billions of dollars (Mittler 2006; IPCC 2007; Battisti and Naylor 2009). Hence, increasing crop productivity in view of escalating population as well diminishing cultivable land and natural resources in such challenging environmental conditions has become a matter of urgency. Although much research has been conducted to evaluate the effects of global warming due to a variety of human activities (Smit et al. 1988), efforts to search specific and practical approaches to improve adaptability of plants to the climate change have only begun recently (Charng et al. 2006; Montero-Barrientos et al. 2010).

Abiotic stresses lead to a series of changes in the plant that affect molecular, biochemical, physiological and phenological processes eventually affecting the performance of plant growth and development impacting overall yield (Wang et al. 2003; Sreenivasulu et al. 2007). Plants that successfully withstand stresses are constantly monitoring their external milieu and are redefining the appropriate cellular response. It depends on the ability of the plants to be equipped with intricate gene regulatory mechanisms leading to the appropriate physiological adaptation to survive harsh challenging conditions. Therefore, understanding plant abiotic stress responses is

\footnotetext{
P. S. Reddy $\cdot$ N. Sreenivasulu $(\bowtie)$

Interdiciplinary Center for Crop Plant Research (IZN) Research Group Stress Genomics, Leibniz-Institute of Plant Genetics and Crop Plant Research (IPK), Corrensstraße 3, 06466 Gatersleben, Germany

e-mail: srinivas@ipk-gatersleben.de
} 
now thought to be one of the most important topics in plant science. Different omicsapproaches have been used to elucidate some of the key regulatory pathways in plant responses to abiotic stresses. The plant physiological and molecular responses to abiotic stresses have been investigated using various genomics strategies (Vij and Tyagi 2007; Collins et al. 2008; Hu et al. 2009), which include transcriptomics (Rostoks et al. 2005; Mohammadi et al. 2007; Zeller et al. 2009), proteomics (Qureshi et al. 2007; Caruso et al. 2009) and metabolomics (Shulaev et al. 2008). For a comprehensive understanding of global response we need to integrate these responses at a systems level and need to build integrative platforms to derive knowledge, which may facilitate development of stress tolerance in crop plants.

A systems biology/omics approach is a new upcoming field in plant biology, which allows not only a better understanding of molecular processes and cellular function (Kitano 2000), but also to identify the molecular targets for crop improvement (Cramer et al. 2011). One of the key challenges of systems biology is to integrate the different omics information to give a more complete picture of living organisms. Such an integrated approach would unravel the complex interplay or cross-talk between the different components and to understand the dynamic activities of a tissue/organ/organism in different environments (Cramer et al. 2011). The availability of these data in model species not only allowed a comprehensive understanding of responses against abiotic stresses, but eventually will make the way forward to identify key targets for engineering abiotic stress tolerance in cereals.

\subsection{Status of Genome Sequences in Cereals}

The genome sequence, often referred to as the genetic blueprint, provides a foundation for connecting the information from the genome to the phenome via structural and functional genomics with an extended approach of systems biology. The development of genomic resources has progressed in a number of plant species, thus creating the gold standard reference genomes in several crops of the grass family including rice, maize, Brachypodium and sorghum. Despite variation in genetic diversity, genome size and chromo-some number, there is substantial conservation in gene order between the grasses which is explored through the study of synteny and collinearity. Extensive data on all aspects of cereal genomics are now available at GrainGenes (http://wheat.pw.usda.gov/) and Gramene (http://gramene .org/), the latter having a major emphasis on rice genome and its syntenic relationship with other cereal genomes. Here, we briefly review the current status of available genomic sequences for cereal crop species (Table 8.1).

\subsubsection{Rice}

Among cereals, the first draft sequence is released in rice in two sub-species japonica and indica (the two subspecies of Asia) by the commercial effort from Syngenta, USA (Goff et al. 2002) and public academic effort by Beijing 


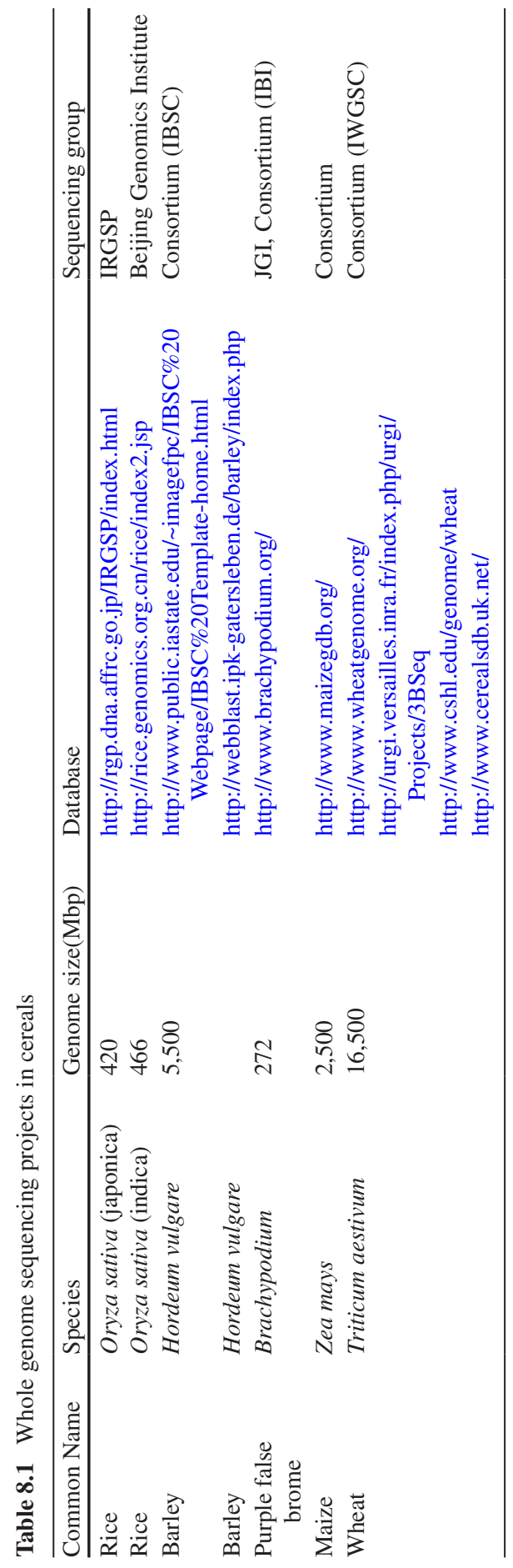


Genomics Institute, China (Yu et al. 2002), respectively. This effort resulted in generating whole-genome shotgun (WGS) genome draft of japonica and indica, covering more than $90 \%$ of the 420 megabase $(\mathrm{Mb})$ genome and also suggested that genome size is increased by $>6 \%$ and $>2 \%$, respectively compared to the common ancestor. Also these two sub-species showed a genetic divergence through a detection of numerous SNPs, indels within both the unique (coding) and the repetitive regions. In 2005, IRGSP released high quality map-based draft sequence in the public domain by providing indexing of 37,544 protein coding genes (International Rice Genome Sequencing Project 2002). Gene predictions developed by the Plant Genomics Group at TIGR (http://rice.plantbiology .msu.edu/) and RAP-DB released the rice genome annotation for the public use (Tanaka et al. 2008). The Rice FOX (full-length cDNA overexpressor) gene hunting system is a resource of gain-of-function mutants where 13,000 full-length rice cDNA clones are overexpressed in Arabidopsis (rice FOX Arabidopsis lines, http://ricefox.psc.riken.jp/) to characterize gene functions in a heterologous system (Kondou et al. 2009; Sakurai et al. 2011). By this way, several fulllength cDNAs from rice were shown to represent function of orthologous genes in Arabidopsis as a FOX line mutant collection with interesting phenotypes (Sakurai et al. 2011).

\subsubsection{Maize}

Maize is an important model $\mathrm{C}_{4}$ cereal crop that is predominantly a cross-pollinating, a feature that has contributed to its broad morphological variability and geographical adaptability. Maize genome size is estimated to be $2,500 \mathrm{Mb}$, which is six times bigger than the rice genome, owing to the expansion of families of transposable elements, particularly retrotransposons (Berhan et al. 1993). The maize genome size has expanded dramatically (up to $2.3 \mathrm{~Gb}$ ) over the last $\sim 3$ million years via a proliferation of long terminal repeats of retrotransposons (SanMiguel et al. 1998). Comparative analysis of grass genomes also reveals conservation of gene order but some local rearrangements interrupt collinearity at molecular level (Feuillet and Keller 2002). These rearrangements often prevent maize gene cloning using other cereals genome sequence information as a reference. Thus, having completed maize genome sequencing is extremely beneficial to better understand gene and genome structure of rice and maize, and to understand the evolution of complex grass genomes. The draft genome of maize B73 has been sequenced (Schnable et al. 2009) using a minimum tiling path of bacterial artificial chromosomes (BACs) $(16,848)$ and fosmid (63) clones derived from an integrated physical and genetic map (Wei et al. 2009), augmented by comparisons with an optical map (Zhou et al. 2009). Shotgun sequenced clones covered up to 4-6 fold genome and followed by automated and manual sequence improvement of the unique regions only, which resulted in the B73 reference genome version 1(B73 RefGen_v1). This B73 RefGen_v1 contains 855 families of DNA transposable elements that make 
up $8.6 \%$ of the genome. From the genome sequence information 32,540 proteinencoding genes and 150 microRNA (miRNA) genes were predicted from assembled B73 RefGen_v1. Exon sizes of maize genes were similar to that of their orthologous genes in rice and sorghum, but maize genes contained larger introns because of insertion of repetitive elements (Wei et al. 2009; Haberer et al. 2005). In future, exploring intraspecific gene variability and a study of the role of epigenetics and retrotransposons will remain an important exercise to resolve the hybrid vigour and plant performance in maize.

\subsubsection{Brachypodium}

The whole genome sequence of Brachypodium reveals that relative to other grass genomes, Brachypodium genome is compact $(272 \mathrm{Mb})$, with retrotransposons concentrated at the centromeres and at the collinearity breakpoints. A total of 25,532 protein-coding genes were predicted in the v1.0 annotation. This is in the same range as sorghum (27,640) (Paterson et al. 2009). Between 77 and $84 \%$ gene families are shared among the three grass subfamilies represented by Brachypodium, rice and sorghum, reflecting a relatively recent common origin (The International Brachypodium Initiative 2010). The similarities in gene content and gene family structure between Brachypodium, rice and sorghum support the value of Brachypodium as a functional genomics model for all grasses. The relatively small genome of Brachypodium contains many active retroelement families, but recombination between these retroelements keeps genome expansion in check. Because of small size and rapid life cycle, and its genetic proximity to tribe Triticeae, Brachypodium has several advantages. The small size of some accessions makes it convenient for cultivation in a small space. This has led to the development of highly efficient transformation systems for a range of Brachypodium genotypes (Vain et al. 2008; Vogel and Hill 2008; Alves et al. 2009). Also several important resources have been developed, which includes germplasm collections (Vogel and Hill 2008; Filiz et al. 2009; Vogel et al. 2009), genetic markers (Vogel et al. 2009), a genetic linkage map (Garvin et al. 2010), bacterial artificial chromosome (BAC) libraries (Huo et al. 2006, 2008), physical maps (Gu et al. 2009), large-scale collection of T-DNA tagged lines termed 'the BrachyTAG program' mutant collections (Thole et al. 2010), microarrays and databases (Table 8.2). These resources are facilitating the use of Brachypodium by the research community, and will allow Brachypodium to be used as a powerful functional genomics resource for grasses. Since Brachypodium is more closely related to the Triticeae (wheat, barley) than to the other cereals, Brachypodium genome also helps in the genome analysis and gene identification in the large and complex genomes of Triticeae tribe (wheat and barley), which are among the world's most important crops. It is also an important advance in grass structural genomics permitting for the first time, whole-genome comparisons between members of the three most important grass subfamilies. 


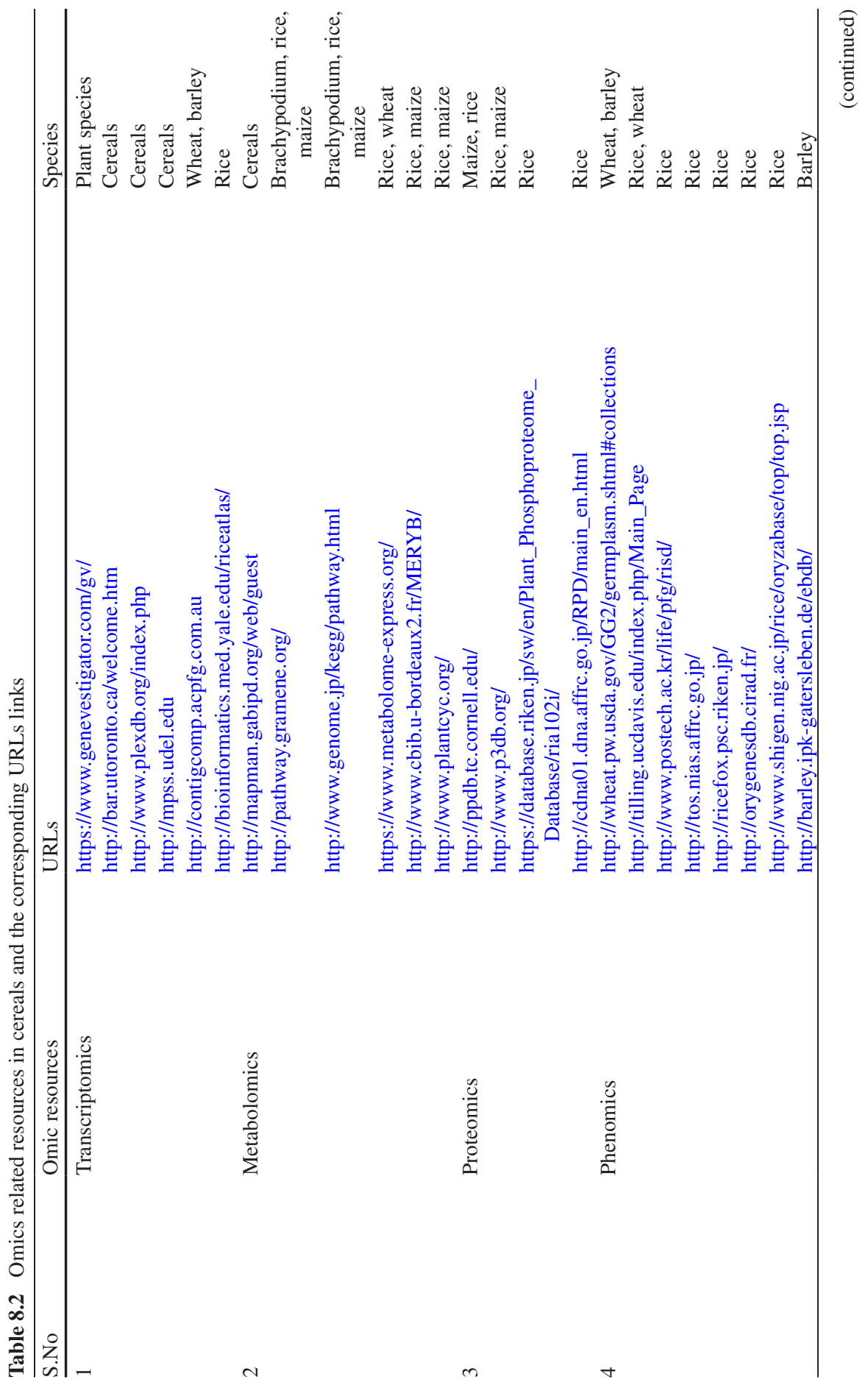




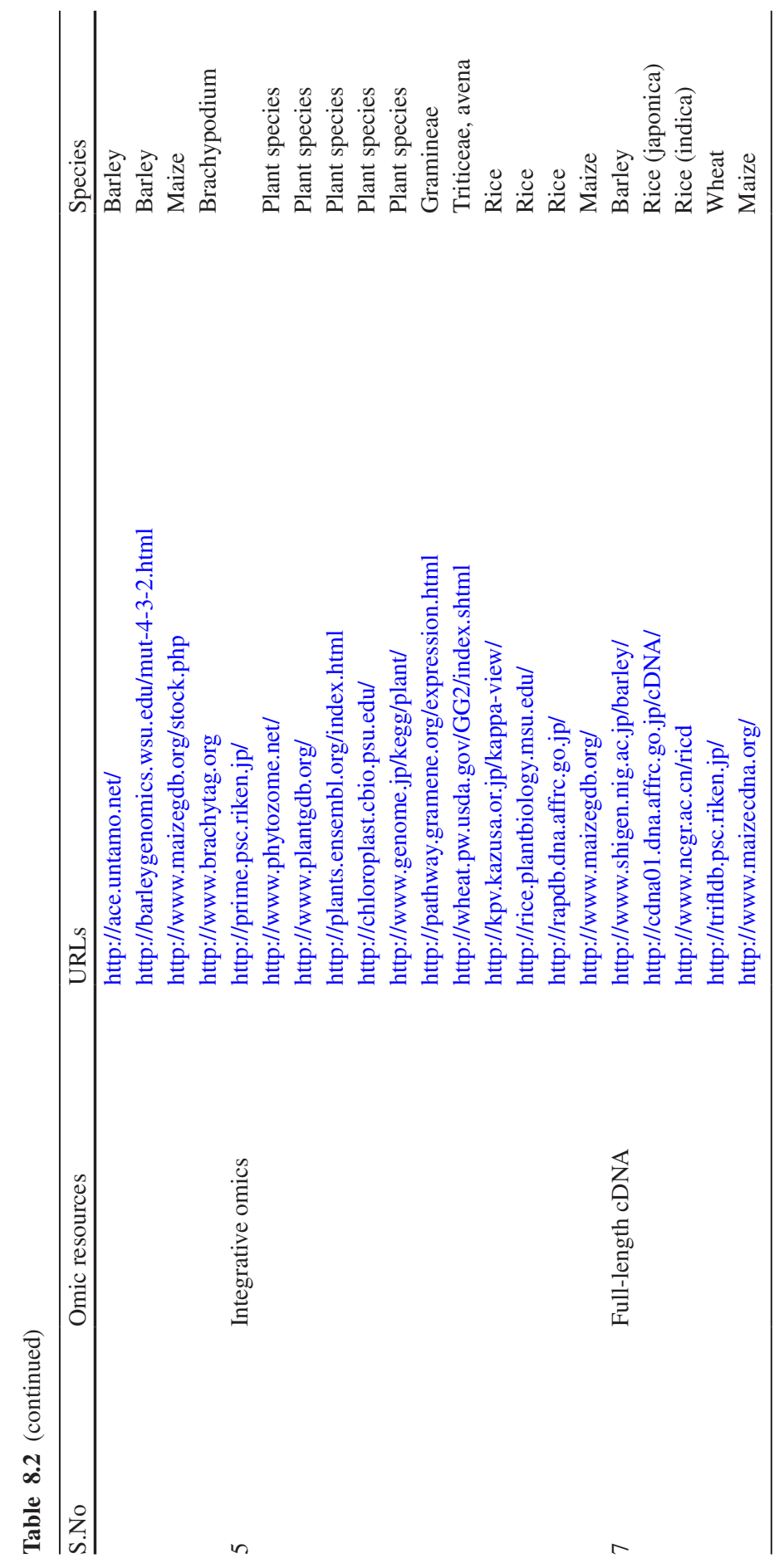




\subsubsection{Barley}

Barley (Hordeum vulgare L.) ranks fourth among the cereals in worldwide production and due to its broad stress tolerance adaptability, high genetic variability and close relationship to wheat and rye, barley is considered as an excellent model $C_{3}$ crop of Triticeae (Koornneef et al. 1997; Hayes et al. 2003; Sreenivasulu et al. 2008a). Barley genome comprises seven chromosomes with estimated genome size of $5,100 \mathrm{Mb}$ (12 times that of rice) of which $80 \%$ of genome is composed of repetitive DNA, which is presently a major challenge to decipher the complete genome. The systematic efforts for sequencing the whole barley genome were initiated in 2006 by International Barley Sequencing Consortium (IBSC) (http://www.public.iastate.edu/ imagefpc/IBSC\%20Webpage/IBSC\%20 Template-home.html) and the cultivar Morex was recommended as a reference genome. Several approaches are being used to unlock the gene content in the whole genome by next-generation sequencing of sorted chromosomes, sequencing of gene-rich BAC clones and full-length cDNA collections (Sreenivasulu et al. 2008b; Mayer et al. 2011; Schulte et al. 2011). As a result, Barley Sequencing Consortium is continuously generating voluminous sequencing data that is accessible from the website (http://webblast.ipk-gatersleben.de/barley/index.php). A novel analytical platform is also available for genome-wide SNP genotyping (9 K Infinium array) for barley and has been used to survey genomic variations among barley germplasm and to evaluate chromosomal distribution of introgressed segments of near-isogenic lines. Also several transcriptome platforms are available to generate genome wide transcriptome atlas (Druka et al. 2006, 2011; Sreenivasulu et al. 2006, 2008a). Natural variants among barley collections were used to investigate the associations between nucleotide haplotypes and growth habits that are witnessed in different geographical distribution (Saisho and Takeda 2011; Pasam et al. 2012).

\subsubsection{Wheat}

Wheat is the most widely grown and important staple cereal crop, which occupies more arable land (17\% of all crop area) and possesses more market share (\$31 billion) than any other cereal crop (Gupta et al. 2008; Safar et al. 2010). Wheat is a hexaploid, with A, B and D subgenomes, the entire genome being 40-fold larger than the rice genome (Arumuganathan and Earle 1991) and each individual subgenome being $\sim 5,500 \mathrm{Mb}$ in size. The large genome size, hexaploid nature and a high proportion of repetitive DNA creates significant challenges in elucidating its genome sequence and to connect genome sequences to the phenotypic variance of agronomic traits (Chantret et al. 2005; Paux et al. 2008; Wanjugi et al. 2009). International wheat genome sequencing consortium (IWGSC) has began to target a complete high quality genome 
sequence, by adopting a chromosome-based strategy to construct physical BAC clone maps and subsequently to sequence each of the individual chromosomes (Dolezel et al. 2007). In this context, around 68,000 BAC clones of a 3B chromosome-specific BAC library (Safar et al. 2004; Paux et al. 2008) have been fingerprinted at the French National Sequencing Centre and the sequencing of these BAC clones is under progress (http://urgi.versailles.inra. fr/index.php/urgi/Projects/3BSeq). Several approaches have been initiated to sequence the complex wheat genome. For instance, the consortium from UK produced 5X sequence of the bread wheat genome using Roche 454 technology (http://www.cerealsdb.uk.net/), and also produced a draft wheat genome assembly from the donor species of the wheat D genome, A. tauschii (http://www.cshl.edu/ genome/wheat). Sequences from individual flow-sorted bread wheat chromosome arms are also piling up gradually (Berkman et al. 2011; Wicker et al. 2011). With the increased availability of wheat genome sequence data, it is necessary to provide resources that can integrate wheat-specific sequence information to become useful for crop improvement (Edwards and Batley 2010). Since wheat genome sequencing is still in progress, and a high quality genome sequence is expecting by 2015 , one can foresee the possibilities of launching systems biology approaches even in barley and wheat. These systematic attempts to move from genomic to post-genomic strategies greatly facilitate researchers who wish to use this information to improve this valuable crop. The update about the genome sequencing project information and other genetic resources are listed in the Table 1.

Evaluating the impact of genome organization, monitoring dynamic alteration of retrotransposons, assessing the impact of epigenetic hallmarks by covering genome wide DNA methylation and omics driven systems biology approaches are all part of genome dynamic applications. In this review we focus on transcriptome, proteome and metabolome data available in cereals and other model species. Further we discuss the future needs of implementing systems biology applications to derive work flow to identify key target genes for crop improvement.

\subsection{Omics Revolution by High Throughput Approaches}

Major progress made in the last decade is through the use of new high-throughput techniques not only in the field of whole genome sequencing but also through characterization of genes through functional genomics. Systematic use of different omics approaches such as transcriptomics, proteomics, metabolomics, fluxome and a way forward to connect the global data to the phenotypic variance (generated through phenomics) have led to expand the area towards systems biology for elucidating the mechanisms underlying the expression of agronomic traits. System-based approaches based on a combination of multiple omics analyses has been an efficient approach to determine the global picture of cellular systems and to reveal the plant responses and adaptation to a specific stress. In this context, the integrated approaches with multiple-omics data should contribute greatly to the 
identification of key regulatory steps and to characterize the pathway interaction in various processes. These illustrative examples demonstrate the power of multiomics-based systems analysis for understanding the key components of cellular systems underlying various plant functions. The integration of a wide spectrum of omics datasets from various plant species is then essential to promote translational research to engineer plant systems in response to the challenges of emerging climate change.

\subsubsection{Transcriptomics}

Genome-wide transcriptome profiling is a powerful approach to assemble a transcriptome atlas of expressed genes involved in various biological phenomena and to reveal the molecular cross-talk of gene regulatory networks of responses to various abiotic stresses. Microarray analysis is known to be an important approach to elucidate the molecular basis of the plant stress response (Van Baarlen et al. 2008; Deyholos 2010). The investigation of gene expression related to several physiological and agronomical traits have been reported in different cereals. These responses include the following: responses to hormones (Seki et al. 2002b; Rabbani et al. 2003), various stress responses (Kreps et al. 2002; Rabbani et al. 2003; Takahashi et al. 2004), including drought (Kreps et al. 2002; Oono et al. 2003; Rabbani et al. 2003), cold (Kreps et al. 2002; Rabbani et al. 2003; Yamaguchi et al. 2004), high light (Rossel et al. 2002; Kimura et al. 2003), hyperosmolarity, oxidative stress (Takahashi et al. 2004), and iron deficiency (Thimm et al. 2001).

More detailed and comprehensive gene expression studies have been conducted in the model species like Arabidopsis and rice, and the resulting knowledge can be used in cereals through comparative gene networks. In case of cereals, several data repositories have been created to store the raw data and normalized expression values generated from GeneChip arrays including Affymetrix $57 \mathrm{~K}$ from Rice, $61 \mathrm{~K}$ Wheat, 22 K Barley1, full-genome Brachypodium and Maize arrays. Furthermore, these databases not only allow storage of data from Affymetrix platform but also allow storing data from Agilent and NimbleGen platforms (Sreenivasulu et al. 2010). These databases include PLEXdb, GEO, Genevestigator, UniProt, PlantGDB (Bombarely et al. 2011) Gramene (Youens-Clark et al. 2011), TAIR (Swarbreck et al. 2008) and MaizeGDB (Schaeffer et al. 2011).

Transcriptome studies have also been carried out in cereals and other model plants but mainly applying single stress at a time such as drought, salinity, cold or heat during the vegetative state (for recent reviews see Ingram and Bartels 1996; Sreenivasulu et al. 2004a, 2007; Kishor et al. 2005; Vij and Tyagi 2007; Fleury et al. 2010). Interestingly, unique stress responsive pathways such as osmolyte metabolism, antioxidant machinery, dehydrin and LEA proteins, chaperones and gene machinery involved in protection of cell integrity are preferentially upregulated in both dicots and monocots (Xue et al. 2006; Ergen et al. 2009; Fleury et al. 2010; Sreenivasulu et al. 2010). However, within osmolyte metabolism, wide 
array of biochemical pathways are known to activate preferentially in a species and genotype specific manner, which corresponds to compounds proline, mannitol, myo-innositol, trehalose, glycine metabolism, accumulation of sugar alcohols and free sugars including fructose metabolism. Additionally, some studies have identified abundance of various transcripts during heat treatment, including genes encoding for galactinol synthase and enzymes in the raffinose oligosaccharide pathway, and antioxidant enzymes (Lim et al. 2006; Xu et al. 2007). Comparison of transcript profiles between tolerant and susceptible lines under various stress responses has revealed differences in stress-responsive pathways reflecting difference in physiological response and adaptation behavior. Transcriptome analysis also revealed some unexpected results such as a decrease in the expression of glutathione-related genes following withholding of water in a tolerant synthetic wheat line (Mohammadi et al. 2007), or the accumulation of proline in a droughtsensitive emmer wheat line (Ergen and Budak 2009), suggesting that some pathways/mechanisms are dependent upon genotype, the duration, intensity, and type of stress applied. There are some reports, which show decrease in transcript abundance related to programmed cell death, basic metabolism, and biotic stress responses (Larkindale and Vierling 2008) under heat stress conditions. Recently, Pinheiro and Chaves (2011) reviewed 450 research papers on drought-mediated changes in photosynthesis.

Until now most of the transcriptome responses have been studied in vegetative tissues and recently few attempts were made to reveal the transcriptome alterations in developing seeds to understand the yield stability. In case of cereals, transcriptome analyses were recently applied to analyze rice developing caryopses under high temperature conditions (Yamakawa and Hakata 2010) and seed developmental alterations in barley under drought (Worch et al. 2011). Overall, several extensive attempts have been made to identify several genes/pathways in a number of cereal crops including rice (Amudha and Balasubramani 2011; Hadiarto and Tran 2011; Yang et al. 2010). However, any deeper and/or new insights into mechanisms of the function of genes were missing. In combination with these reviews, the present review of literature based on transcriptome studies should present a pertinent update on genes involved in abiotic stress tolerance in crop plants. The effort is to lend a perspective on how different pieces may fit into the complicated puzzle and to present the integrated view on abiotic stress tolerance.

\subsubsection{Proteomics}

Although transcriptomics data provides an useful overview of global gene expression regulation, proteomics is often used as a complementary technique that provides the actual state of the condition of cell response to stress. Moreover, proteomics is considered as an essential bridge between the transcriptome and the metabolome (Wasinger et al. 1995; Zhu et al. 2003). Compared to transcriptome 
analysis, proteomics approach has a close relationship to phenotype because of their direct action on several biochemical processes. This approach is important in evaluating stress responses since the mRNA levels may not always correlate with protein accumulation (Gygi et al. 1999) and moreover several regulatory proteins are subjected to proteolysis to fine tune the dynamics of transcribed machinery. Despite this strategic importance, compared to transcriptomics analysis, plant proteome response to abiotic and biotic stresses is still limited.

In the last decade, good progress has been made in the separation of proteins and their identification by mass spectrometry. Studies have evaluated changes in protein levels of plant tissues in response to stresses (Canovas et al. 2004; Kim et al. 2003). However, these studies have mainly focused on model species such as Arabidopsis and rice (Canovas et al. 2004). Implication of proteomic studies in cereals is mainly based on rice as a model species (Agrawal and Rakwal 2006, 2011; Komatsu and Yano 2006). A proteomic analysis of drought and salt-stressed rice plants found that around 3000 proteins could be detected in a single gel and over 1,000 could be analyzed (Salekdeh et al. 2002). The effect of salt stress on young rice panicles has been investigated by the same group (Dooki et al. 2006). The proteomic analysis of rice leaf sheaths during drought stress identified 10 up-regulated and two down-regulated proteins. Among the up-regulated proteins, one was an actin depolymerizing factor present at high levels in the leaves of non-stressed drought-resistant cultivars (Ali and Komatsu 2006). Proteome reference maps have been compiled for maize (Mechin et al. 2004) and wheat (Vensel et al. 2005) endosperm and for barley grain (Finnie et al. 2002) during the processes of grain filling and maturation. The effect of heat stress on the grain of hexaploid wheat has been thoroughly studied at the protein level and down-regulation of several proteins involved in the starch metabolism and the induction of HSPs was reported (Majoul et al. 2003, 2004). The effect of drought on the wheat grain proteome, involved 121 proteins that exhibited significant changes in response to the stress; 57 of these 121 proteins could be identified (Hajheidari et al. 2007). Two-thirds of the identified proteins turned out to be thioredoxin targets, revealing the link between drought and oxidative stresses. Changes in the protein complement have been monitored in maize under progressive water deficit and several genes/proteins were reported to be involved in the drought response (Riccardi et al. 1998). The high level of genetic variability observed at the proteome level for the drought response in maize (de Vienne et al. 1999) allowed identification of Asr 1 (ABA/ water-stress/ripening-related1) gene as a candidate for genetic improvement (Jeanneau et al. 2002). Apart from this, some proteomics resources are also available for grasses, such as the plant proteome database (http://ppdb.tc.cornell.edu/) which provides information on the maize and Arabidopsis proteomes. RIKEN Plant Phosphoproteome Database (RIPP-DB, http://phosphoproteome.psc. database.riken.jp) was updated with a data set of large-scale identification of rice phosphorylated proteins (Nakagami et al. 2010, 2012). The OryzaPG-DB was launched as a rice proteome database based on shotgun proteomics (Helmy et al. 2011). Although only a handful of studies have been carried out in cereal 
crops, it is expected to have a significant increase in the implementation of these techniques in cereal crops to study genome wide protein-protein interactions.

\subsubsection{Metabolomics and Fluxome}

Metabolomics is one of the important component of functional genomics. It defines the quantitative metabolite signatures present in a cell/tissue under a given set of physiological conditions (Oliver et al. 1998; Kell et al. 2005; Jordan et al. 2009). Higher plants have the remarkable ability to synthesize a vast array of compounds that differ in the chemical complexity, structure and biological activity, playing indispensable roles in chemical defenses against biotic and abiotic stresses (Verpoorte and Memelink 2002; Dixon and Strack 2003; Schwab 2003). Moreover, under various stress conditions, crop species are known to modulate the primary metabolism due to the impaired photosynthesis and respiration events. The main advantage of metabolomics is that it allows one to measure the impact of metabolism and to interlink the key metabolic signatures to the phenotype.

Study of metabolic regulation during stressful conditions has been facilitated through mass spectrometry-based analytical methods resulting in the detection and identification of diverse metabolites (Sawada et al. 2009). Metabolite profiling deals with detection of a wide range of metabolites in diverse concentrations, which makes their analysis more complicated. Therefore, more comprehensive coverage can only be achieved by using multi-parallel complementary extraction and detection technologies subjected to chemical analysis using liquid and gaseous chromatography-mass spectrometry (LC-MS and GC-MS), nuclear magnetic resonance (NMR) and Fourier transform-infrared spectrometer (FT-IR).

Metabolome analyses of model plants have markedly increased in the recent decade and helped to understand the plant response to various stresses. To obtain deeper view into cellular conditions under abiotic stresses, metabolomic investigations have been performed initially in model species like Arabidopsis and other plant species (Schauer and Fernie 2006). From the genome sequence information of the A. thaliana, it is evident that plants appear to re-organize their metabolic network in order to adapt to such conditions (Kaplan et al. 2004). Therefore, metabolomics plays a key role in understanding cellular functions and decoding the functions of genes under challenging abiotic stress conditions (Fiehn 2002; Bino et al. 2004; Oksman-Caldentey and Saito 2005; Hall 2006; Schauer and Fernie 2006; Hagel and Facchini 2008; Saito et al. 2008). Metabolic adjustments in response to different stress conditions are dynamic and multifaceted because of their intensity and nature of the stress, but it also depends on the cultivar and the type of plant species. This approach also covers the extensive comprehensive metabolite analyses, illustrating the complexity of metabolic adjustments to different abiotic stresses (Rizhsky et al. 2004; Urano et al. 2009) including salinity (Cramer et al. 2007; Kempa et al. 2007; Sanchez et al. 2008; Janz et al. 2010; Lugan et al. 2010), and temperature stress (Cook et al. 2004; Rizhsky et al. 2004; 
Kaplan et al. 2007; Usadel et al. 2008; Espinoza et al. 2010; Caldana et al. 2011). Some metabolic changes are common to salt, drought, and temperature stress, whereas others are specific to particular stress (Gong et al. 2005; Cramer et al. 2007; Gagneul et al. 2007; Kempa et al. 2008; Sanchez et al. 2008; Usadel et al. 2008; Urano et al. 2009; Lugan et al. 2010). Metabolomic profiles illustrate that plants have developed a wide range of strategies to adapt their metabolism to unfavorable growth conditions and that enhanced stress resistance is not restricted to a single compound or mechanism. Several metabolites/metabolic pathways that contribute to stress acclimation also play a role in development (Hanzawa et al. 2000; Samach et al. 2000; Eastmond et al. 2002; Palanivelu et al. 2003; Imai et al. 2004; van Dijken et al. 2004; Alcazar et al. 2005; Gupta and Kaur 2005; SatohNagasawa et al. 2006; Mattioli et al. 2008, 2009; Szekely et al. 2008; Deeb et al. 2010; Zhang et al. 2011).

Surprisingly, metabolomic research has made a limited progress in cereals. A recent metablolome study in rice identified 88 metabolites from the extract of leaves. It was found that sugar and amino acid metabolism is dynamically altered under stress treatment (Sato et al. 2008). Metablolome study from maize kernels showed wide range of natural variability based on the influence of genetic background and growing season (Reynolds et al. 2005), developmental stages (Seebauer et al. 2004) and environment (Harrigan et al. 2007). Metabolome study of diverse maize genotypes recently explored and highlighted the importance of grain fatty acid methyl esters, free fatty acid methyl esters, free amino acids. Around 167 metabolites were identified from 300 distinct analytes by using GC-MS approach (Rohlig et al. 2009). Integrated metabolome and transcriptome analysis has also been applied to investigate changing metabolic systems in plants growing in field conditions, such as the rice Os-GIGANTEA (Os-GI) mutant and transgenic barley (Kogel et al. 2010; Izawa et al. 2011). The application of metabolomics in cereals has just begun, and its full potential will be realized only in future. Large-scale metabolic analyses are therefore necessary to observe the metabolic networks important for plant growth and development under a range of environmental conditions.

Measurement of metabolism-wide fluxes through steady-state metabolic flux balance analysis (MFA or FBA) by measuring ${ }^{13} \mathrm{C}$ redistribution signatures within the primary metabolism at subcellular compartment level, and the information about the biomass composition and growth rate generate data, which is collectively described as Fluxome. Predicted flux maps is an important part of metabolic engineering (Becker et al. 2007). Recently, several methods are refined to predict metabolic networks that determine the fluxes, which directly report on cellular physiology. The most widely used approaches for fluxome analysis are based on GC-MS measurement of labelling pattern of metabolites from the tracer studies. This approach is optimized and applied to move from gaining information of static metabolic signatures to end products. A recent approach to the fluxome consists of the comprehensive determination of enzyme activities from cyclic robotic assays and determination of the activity of each reaction step in the metabolic pathway (Gibon et al. 2006; Osuna et al. 2007). The most direct information 
of metabolic regulations can be obtained through the determination of an actual metabolic flux. This method also allows gaining precise knowledge of metabolic physiology and its engineering (Christensen and Nielsen 2000; Des Rosiers et al. 2004). A range of different MFA methods has been applied to plant systems, resulting in identifying unique insights into the operation of plant metabolic networks. Implementing the emerging MFA methods for plant studies faces considerable hurdles because of the greater complexity of plant metabolic networks and our ignorance of understanding the biochemical pathway and kinetics at sub-cellular compartment levels (Sweetlove et al. 2008). For metabolic flux calculation, the different labelling data obtained are usually utilized to globally fit the unknown flux parameters by a computer flux model combining isotopomer and metabolite balancing strategies (Wiechert et al. 2001; Kiefer et al. 2004; Wittmann et al. 2004; Frick and Wittmann 2005). It has been recognized that better optimization of experimental designs is essential for distinguishing activities between parallel metabolic pathways operative in distinct cellular compartments, such as cytosol and plastids (Allen et al. 2007; Kruger et al. 2007; Li et al. 2008). Overall, MFA and dynamic labeling methods are instrumental for quantifying metabolic fluxes of plant responses under ambient and challenging environments (Roscher et al. 2000; Boatright et al. 2004; Matsuda et al. 2005; Ratcliffe and Shachar-Hill 2006; Matsuda et al. 2009). Recently, genome wide metabolic fluxes have been predicted in Arabidopsis for high temperature and hyperosmotic stress, so that it was possible to identify key signatures such as severe reduction in carbon-use efficiency through reduction in PEP flux and increased TCA cycle for altered growth rate (Williams et al. 2010). Fewer studies have applied MFA in cereals. In maize, fastgrowing excised root tips were used to study the central carbon metabolism by keeping them for $12-18 \mathrm{~h}$ in a medium containing ${ }^{13} \mathrm{C}$-labeled glucose (DieuaideNoubhani et al. 1995; Edwards et al. 1998), and then analyzing the most abundant labeled free intracellular metabolites (i.e., sugars and amino acids) by NMR or MS; large flux maps of central carbon metabolism were derived in this manner (Dieuaide-Noubhani et al. 1995; Alonso et al. 2005). In other studies ${ }^{13} \mathrm{C}$ labeled glucose was used to label maize kernels and barley caryopsis, and label was analyzed in both glucose (derived from starch) and amino acids (derived from proteins) available in the starchy endosperm (Glawischnig et al. 2001, 2002; Grafahrend-Belau et al. 2009; Rolletschek et al. 2011).

\subsubsection{Role of Hormones}

Abiotic stress response involves a trigger of similar set of transcription factors involved in both ABA-dependent and ABA-independent manner in both dicotyledonous and monocotyledonous plants (reviewed by Sreenivasulu et al. 2007). Genes differentially regulated in Arabidopsis and rice in response to drought, salinity and cold stress comprise gene-sets enriched with DRE-related and ABRE core motifs. Therefore both ABA-dependent and ABA-independent 
signaling pathways are important in regulating the transcriptome responses (Seki et al. 2002a, 2001; Gomez-Porras et al. 2007). Abscisic acid (ABA) remains the best-studied hormone for plant stress response. However, other hormones such as cytokinins, auxins, gibberellins, brassinosteroids, strigolactones, jasmonic acid, salicylic acid as well as the gaseous hormones, ethylene and nitric oxide are being studied for their role in abiotic stress response in the recent past. Hence, we need to understand the manipulation of the phytohormone synthesis and action across the plant life-cycle, which is an attractive avenue to understand and engineer abiotic stress tolerance. In barley, the response to salinity stress includes the synthesis and the induction of the jasmonate signalling transduction pathways (Walia et al. 2006, 2007). Recently, modification of cytokinin expression, with the critical difference in the use of a stress and maturation-induced promoter in rice resulted in elevating drought tolerance to produce higher yield under stress (Peleg et al. 2011). The observed differences in the content of other phytohormones in the cytokinin-modulated transgenic rice lines also suggested synergistic or antagonistic interactions between auxins, ethylene, cytokinins and ABA in regulating stomatal behavior. Furthermore, gibberellins and brassinosteroids have a strategic importance in tolerance to a variety of abiotic stresses (Peleg and Blumwald 2011). Critical alteration in the ratio of cytokinins and abscisic acid and its antagonistic responses is known to alter the growth dynamics under abiotic stress response (Nishiyama et al. (2011). Also, the effects of three different phytohormones auxin, ABA and cytokinins on the single trait of nitrogen acquisition were reported in a recent review (Kiba et al. 2011). Nitrogen acquisition and remobilization is an important trait to be considered in abiotic stress tolerance to fine tune source-sink relationships in enhancing grain yield (Seiler et al. 2011; Kohli et al. 2012).

\subsubsection{Phenomics}

Phenomics involves comprehensive capture of a plant's phenotype that helps to explore the germplasm. Unfortunately, there is a large gap in our understanding of events that may occur when genotype is translated into phenotype; there is an urgent need to fill this gap (Zamboni and Sauer 2004; Furbank and Tester 2011). Plant genomes possess great plasticity in the genomes for producing various types of phenotypes. However, the genetic variability that may prove useful for developing stress tolerant lines is limited.

There are large number of initiatives launched (IPPN: International Plant Phenomics Network; DPPN: Deutsches Pflanzen Phänotypisierungs Netzwerk; EPPN: European Plant Phenotyping Network; APPF: Australian Plant Phenomics Facility) to create phenotyping facilities to screen populations, GMO material and mutant collections by employing high end image capture technologies in the phytotrons and glass houses. The Plant Accelerator (Lemnatech scan analyzer 3D) which takes non-destructive measurements of plant biomass (Finkel 2009) can also be 
used. The core of the Plant Accelerator's phenotyping facility also measures level of watering and nutrient supplementation control, managing plant movement and tracking, and records images of plants in a range of different wavelengths, thus providing enormous information about the diversity of phenotype. Visible cameras quantify overall plant morphology, size, colour, shoot mass and other physical characteristics; near infra-red cameras detect water content of the leaves and soil; far infra-red provides information about leaf temperature and transpiration rate. While UV detects chlorophyll fluorescence, the GFP fluorescence will be helpful to monitor transgene expression. The first phenomics study was the use of quantitative phenotypic assays to measure salt tolerance traits such as osmotolerance $\mathrm{Na}^{+}$exclusion and $\mathrm{Na}^{+}$tissue tolerance in the diploid wheat T. monococcum (Rajendran et al. 2009). The advantage of this approach is that it is non-invasive, allowing other omics approaches to analyze cell products from the same plant. Also other non-invasive techniques such as magnetic resonance imaging, high resolution based nuclear magnetic resonance and positron emission tomography are implemented to gain insights into structurefunction relationship (reviewed by Mir et al. 2012). To fully explore the genotype dependent tolerance mechanisms within the breeding programs, field-based highthroughput phenotyping platforms are essential to monitor the canopy temperature using infrared thermography. Furthermore, implementations of remote sensing technologies are essential to fully explore phenotypic plasticity at the field level. To explore the key agronomic traits for the improvement of sustainable agriculture, one needs to expand the systematic phenotyping to explore allelic variation in mapping populations, breeding programs and large scale mutants and GMO collections.

\subsection{Integrative Systems Biology}

Integration of the different omic approaches in the area of abiotic stress tolerance allows more robust identifications of molecular targets for future biotechnological applications in crop plants. Manipulating plant metabolism to better serve the future needs requires an improved understanding of the links between genotype and phenotype. Therefore, the massive omics data created from multifaceted platforms of genome, transcriptome, proteome, metabolome, flux and enzyme kinetics (Table 8.2 and Fig. 8.1) need to be interlinked to the cellular phenotype to understand the cellular physiological status under perturbed environmental conditions (Sauer et al. 1999). To address the missing links between molecules and physiology, different approaches of systems biology are implemented which includes "top-down" and "bottom-up" strategies. The major strengths of top-down systems biology are to gain an integrative view of the huge collection of omic data sets like transcriptomics and/or proteomics, metabolomics and fluxomics (Westerhoff and Palsson 2004). Top-down systems biology identifies molecular interaction networks on the basis of correlated molecular behavior observed through genomewide 'omics' studies. Also, bottom-up systems biology deduces the functional properties that could emerge from a subsystem that has been characterized to a 


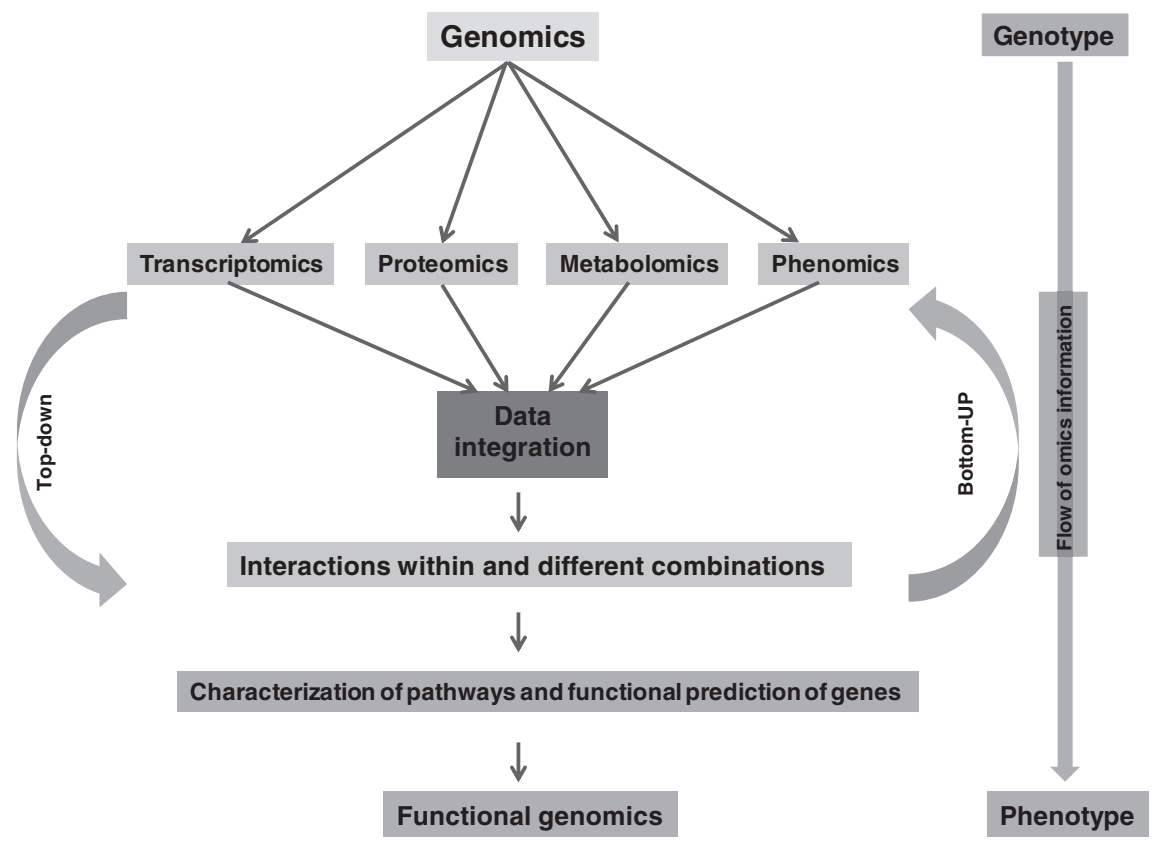

Fig. 8.1 Schematic representation of omics integration pipeline used in systems biology srategies

high level of mechanistic detail using molecular methods but focuses at the cellular level. By employing the systems biology tools in plant science, many abiotic stressinducible genes were identified and their functions were precisely characterized in the model species.

Also, top-down systems biology concerns the identification of the structure of the molecular network that underlies system behavior that is, 'reverse engineering' from system data alone. Top-down approach starts by (re)constructing a possible topology of the network at a low level of complexity and provides a broad overview of the system at low resolution. Transcriptional networks through reverse engineering methods from the collections of gene expression data have been well pioneered on single-cell organisms, but have increasingly been applied to higher order organisms including plants where applications of systems biology methods are now emerging (Carro et al. 2010; Carrera et al. 2009; Needham et al. 2009). The available network models are mainly based on Boolean, Relevance, or Bayesian networks or association rules (Hache et al. 2009). These network inference methods are categorized into (1) those that aim to influence the genes in the general manner to influence the expression of other genes by forming gene regulatory networks (Bansal et al. 2007; Marbach et al. 2010) and (2) those, which aims to having physical interaction between transcription factors and the regulatory genes/motifs by forming the gene regulatory networks (Styczynski and Stephanopoulos 2005). The metabolic 
network reconstructions that are normally done at the genome-scale are the key factors to characterize the genotype to phenotype relationships using all sequence and functional annotation data that is available in public databases combined with manual curation using the available literature and experimental data (Feist et al. 2009). Most systems biology studies have been implemented in the model plant Arabidopsis, where large transcriptomics programs have generated adequate quantities of high-quality data to enable systems analysis (Krishnan et al. 2009). The resulting knowledge can be used in cereals through comparative gene networks. Therefore, it is important to perform parallel studies in cereals with other characteristics, as well as to develop methods to allow use of data from the Arabidopsis system to conduct studies in other plant species.

Integration of different multiple 'omics' data is required to reconstruct complex networks that characterize the phenotypes in the cell (Moles et al. 2003; Kremling et al. 2004). In particular, transcriptome co-expression analysis for delimiting genes of interest has been implemented more efficiently using publicly available large transcriptome datasets such as AtGenExpress (Schmid et al. 2005; Goda et al. 2008) and NASCArrays (Craigon et al. 2004), which contain data from $>1000$ microarrays from model species alone. This kind of in-depth data is yet to be generated among cereal species to elucidate gene regulatory networks. The current status of available resources related to integrated databases for cereal crop species are listed in the Table 2. Transcriptome data sets are now available for co-expression analysis of the transcriptome in cereal crops; for instance, RiceArrayNet and OryzaExpress databases provide web-accessible co-expression data for rice (Lee et al. 2009; Hamada et al. 2011). The ATTED-II database also provides co-expression data sets for rice in addition to those for Arabidopsis (Obayashi et al. 2007; 2011). A co-expressed barley gene network was recently generated and then applied to comparative analysis to discover potential Triticeae- -specific gene expression networks (Mochida et al. 2011). PlaNet (http://aranet.mpimp-golm. mpg.de/), a database of co-expression networks for Arabidopsis and six plant crop species, uses a comparative network algorithm, NetworkComparer, to estimate similarities between network structures (Mutwil et al. 2011). This platform integrates gene expression patterns, associated functional annotations and MapMan term-based ontology, and facilitates knowledge transfer from Arabidopsis to crop species for the discovery of conserved co-expressed gene networks. The KEGG PLANT Resource (KEGG; http://www.genome.jp/kegg/) is one of the most widely established integrated database which provide information on primary metabolism of biosynthetic pathways. It aims to integrate genomic information resources with the biosynthetic pathways of natural plant products (Masoudi-Nejad et al. 2007). Another information resource for biosynthetic pathways, PlantCyc platform has been used for a number of plant species to analyze the computational analysis of the genes, enzymes, compounds, reactions and pathways involved in developmental and stress response. The pathways section in the Gramene databases provides RiceCyc, MaizeCyc, BrachyCyc and SorghumCyc, for rice, maize, Brachypodium and sorghum, respectively (http://www.gramene.org/pathway/). These resources will enable cereal workers to focus on active analysis of regulatory networks that 
may be involved in different biological functions (de la Fuente et al. 2002; Vlad et al. 2004; Kholodenko et al. 2002).

Generally, a preselected set of genes designated as guide genes or bait genes for the core part of the network modules is computed for co-expression with other genes for the generation of co-expression networks (Horan et al. 2008). If a network frame is formed between unknown and known genes, it is presumed that these genes share a common regulatory system and thus are involved in the same pathway. This approach was applied for identification of genes involved in several biochemical pathways such as cellulose synthesis (Persson et al. 2005), aliphatic glucosinolate biosynthesis (Hirai et al. 2007), glucosinolate biosynthetic pathway (Hansen et al. 2007; Geu-Flores et al. 2009) and hormone metabolism (Goda et al. 2008). In case of cereals, the integrated analysis of metabolome and transcriptome was recently conducted to analyze rice caryopses developing under high temperature conditions (Yamakawa and Hakata 2010); molecular events underlying pollinationinduced and pollination-independent fruit sets were also examined (Wang et al. 2009). Integrated analysis of metabolome and transcriptome has also been applied to investigate changing metabolic systems in field grown plants of rice Os-GIGANTEA (Os-GI) mutant and transgenic barley lines (Kogel et al. 2010; Izawa et al. 2011). An integrated analysis of proteome and metabolome was also used to compare the differences in response to anoxia between rice and wheat coleoptiles (Shingaki-Wells et al. 2011). Furthermore, an integrated analysis of transcriptome, proteome and metabolome was conducted to characterize the cascading changes in UV-B-mediated responses in maize (Casati et al. 2011). In this context, the integrated approaches with multiple omics data should contribute greatly to the identification of key regulatory steps and to characterize the pathways for various processes. Following these successful efforts, multi-omicsbased systems analyses have improved our understanding of plant cellular systems by integrating metabolome analysis with genome and transcriptome resources (Hirai et al. 2004; Saito et al. 2008; Okazaki et al. 2009). The URLs of each integrative database in plant genomics are listed in Table 2 .

The main objective of the above strategy is to discover new molecular mechanisms using an iterative cycle that starts with experimental data, followed by data analysis and data integration to determine correlations between the molecules. As an end process, the formulation of hypotheses concerning co- and inter-regulation of groups of those molecules will be revealed. The omics data obtained under a specific condition such as stress response from a given gene knockouts are used for integrated omics analysis in this strategy. Such an analysis allowed the prediction of functional relevance of key genes involved in stress-specific regulons determining tolerance. This approach has become the key to decipher the functional analysis of the genes identified from the whole genome sequencing of the plants. Alternatively, it also helps to identify ubiquitous stress regulated pathways. However, more attention is now focused in the creation of mutants and screening the response to abiotic stress using multi-layered omics strategy. To date, more than half a million T-DNA mutants have been developed for rice and Arabidopsis (An et al. 2005; O'Malley and Ecker 2010). In other cereals, like Brachypodium, a large-scale collection of T-DNA tagged lines termed 'the BrachyTAG program' have been developed and 
used to investigate gene functions (Thole et al. 2010). A collection of several knockout mutants in cereals has been generated to assess the function of genes involved in abiotic stress. The rice full-length cDNA overexpressed Arabidopsis mutant database (Rice FOX Database, http://ricefox.psc.riken.jp/) was a new information resource for the FOX line (Sakurai et al. 2011). The system was also used to screen salt stress-resistant lines in the $\mathrm{T}_{1}$ generation produced by the transformation of 43 focused stress-inducible transcription factors of Arabidopsis (Fujita et al. 2007). Then, the system was applied to a set of full-length rice cDNA clones aiming for in planta high-throughput screening of rice functional genes, with Arabidopsis as the host species (Kondou et al. 2009). Thus, the FOX hunting system is capable of the high-throughput characterization of gene functions. Furthermore, in rice, the endogenous retrotransposon Tos 17, which is activated in particular conditions, is also available for the study of the insertion mutant lines of a japonica rice cultivar, Nipponbare (Miyao et al. 2007). Several mutants were isolated in wheat, which showed increased resistance towards biotic stress tolerance. In wheat, heat tolerant (Mullarkey and Jones 2000) and salt tolerant plants (Huo et al. 2004) have already been charecterized to study the genetic basis of stress tolerance. Additionally, the maize Enhancer/Suppressor Mutator (En/Spm) element has also been used as an effective tool for the study of functional genomics in plants (Kumar et al. 2005). Other approach to study the gain-of-function of mutations by activation tagging have been developed and performed in Arabidopsis, rice and soybean (Weigel et al. 2000; An et al. 2005; Kuromori et al. 2009). The current status of available resources related to mutants database for cereal crop species were listed in the Table 8.2.

\subsection{Identification of Key Candidate Genes for Tolerance to Abiotic Stress and Validation of their Functions Using Transgenic Approaches}

One of the key challenges facing agriculture today is the acute water shortage and high temperature caused by worldwide climate change and the increasing world population. Fulfilling the needs of this growing population is quite difficult from the limited arable land area available on the globe. Although there are legal, social and political barriers to the utilization of biotechnology, advances made in this field have great potential to substantially improve agricultural productivity under challenging environments. Both non-GMO and GMO strategies have been implemented to improve tolerance in crop plants. Genetic engineering is thus being intensively explored to improve plant tolerance to various abiotic stresses, and transgenic crop genotypes with improved stress resistance have actually been produced (Bartels and Sunkar 2005; Vinocur and Altman 2005; Umezawa et al. 2006; Pennisi 2008; Wan et al. 2009). In case of maize, drought tolerance transgenics are also undergoing field trails in Africa, and some other drought tolerant genotypes are also being used by the farmers for commercial cultivation. Performance of a number of other events in maize and other crops are being subjected to field trials. Partial drought 
tolerance has been achieved in the vegetative phase through gene transfer by altering the accumulation of osmoprotectants, production of chaperones, protection of cell integrity by expression of LEA proteins and improved superoxide radical scavenging mechanisms (see reviews by Hasegawa et al. 2000; Kishor et al. 2005; Sangam et al. 2005; Sreenivasulu et al. 2004b, 2007; Vij and Tyagi 2007). In addition, overexpression of the key regulators $\mathrm{ABF} 2, \mathrm{ABF} 3$ and $\mathrm{ABF} 4$ of Arabidopsis involved in ABA-dependent signaling as well as constitutive expression of the Arabidopsis DREB1A, DREB1B, DREB1C and DREB2A transcription factors participating in ABA-independent signaling pathways have been shown to be effective in engineering drought tolerance (see reviews by Agarwal et al. 2006; Umezawa et al. 2006; Sreenivasulu et al. 2007). Genetic engineering strategy has been successfully applied to increase tolerance against a number of other abiotic stresses also. In this context, a variety of crops from cereals (rice, maize, barley, Brachypodium and wheat etc.,) have been engineered for enhanced resistance to a multitude of stresses, each individually, or in combination of biotic and abiotic stresses. Enhancing plant tolerance to abiotic stresses involves multiple mechanisms and therefore involves manipulation of different physiological and biochemical pathways (Wang et al. 2003; Zhang et al. 2009).

\subsection{Summary and Outlook}

The availability of complete genome sequence information of model species like Arabidopsis thaliana, Oryza sativa and other cereal plants has made valuable contributions in dissecting the stress response at the level of transcriptional regulation, posttranscriptional, post-translational modifications and epigenetic regulation. Using high throughput modern techniques like transcriptomics, metabolomics and proteomics, stress-responsive pathway genes have been identified. These strategies enabled us to identify key stress regulators by deriving complicated regulatory network. Employing the systems biology tools in plant science, many abiotic stress-inducible genes were identified and their functions were precisely characterized in the model species.

The identification of stress-regulators gave rise to the idea that plants have developed flexible cellular response mechanisms to efficiently respond to various abiotic stresses. Numerous genes that are induced by various abiotic stresses have been identified using various microarray systems and these gene products are classified into two groups. The first group includes proteins functioning in direct abiotic stress tolerance; these include the following: chaperones, LEA proteins, osmotin, antifreeze proteins, mRNA-binding proteins, key enzymes for osmolyte biosynthesis such as proline, water channel proteins, sugar and proline transporters, detoxification enzymes, and enzymes involved in fatty acid metabolism, proteinase inhibitors, ferritin, and lipid-transfer proteins. The second group includes factors involved in regulatory function related to signal transduction, hormonal response and transcription factors, which are responsive to various stress factors. These transcription factors could regulate various stress inducible genes cooperatively or independently, and may constitute gene networks. 
Under drought, photosynthesis is affected by decreased intake and diffusion of $\mathrm{CO}_{2}$ due to modulation of stomatal opening by phytohormones. In response to altered carbon intake, the changed leaf sugar status acts as a metabolic signal. In concert with other phytohormones, it inhibits growth, which further alters the carbon: nitrogen ratio. The stress conditions generated by severe drought and nutrient deprivation triggers energy imbalances, as well further loop-in alteration between growth promoting and growth retarding phytohormones (Sreenivasulu et al. 2012), generation of reactive oxygen species (ROS) and second messengers such as calcium to affect transcriptional regulation of numerous genes. Their meta-analysis indicated that variables on the time and severity of stress and plant species made it difficult to find a general trend in relating molecular responses to the physiological status of the plant. Functional characterization of stress inducible transcription factors should provide more information in the complex regulatory gene networks that are involved in responses to drought, high temperature, and high salinity stresses. At present, the functions of many of these genes are not fully characterized. Some attempts at analyzing large scale high throughput data allows us to bring the different elements together, suggesting that the integration of stress cues into development and plant growth in dealing with crop yield under stress is rather complicated. Such diversity in needs, approaches, opinions and indeed results has led to generation of massive literature, which needs to be systematically reviewed to derive proper strategies for understanding the stress tolerance mechanisms. Therefore methods implied in systems biology approaches remain pivotal to systematically reveal the function of these stress-responsive pathways.

Acknowledgments NS is thankful to research funding obtained through BMBF (IND 09/526), BLE grant 511-06.01-28-1-45.041-10, BMZ grant 81131833 and from the Ministry of Education Saxony-Anhalt (IZN). PS acknowledge the Leibniz-DAAD post doctoral fellowship award (Number: A/11/94309) from Germany Academic Exchange programme (DAAD), Germany. We acknowledge the help of Prof. P.K. Gupta for the editorial changes which helped to improve the manuscript.

\section{References}

Agarwal PK, Agarwal P, Reddy MK, Sopory SK (2006) Role of DREB transcription factors in abiotic and biotic stress tolerance in plants. Plant Cell Rep 25:1263-1274

Agrawal GK, Rakwal R (2006) Rice proteomics: a cornerstone for cereal food crop proteomes. Mass Spectrom Rev 25:1-53

Agrawal GK, Rakwal R (2011) Rice proteomics: a move toward expanded proteome coverage to comparative and functional proteomics uncovers the mysteries of rice and plant biology. Proteomics 11:1630-1649

Alcazar R, Garcia-Martinez JL, Cuevas JC, Tiburcio AF, Altabella T (2005) Overexpression of ADC2 in Arabidopsis induces dwarfism and late-flowering through GA deficiency. Plant J 43:425-436

Ali GM, Komatsu S (2006) Proteomic analysis of rice leaf sheath during drought stress. J Proteome Res 5:396-403

Allen DK, Shachar-Hill Y, Ohlrogge JB (2007) Compartment-specific labeling information in 13C metabolic flux analysis of plants. Phytochemistry 68:2197-2210 
Alonso AP, Vigeolas H, Raymond P, Rolin D, Dieuaide-Noubhani M (2005) A new substrate cycle in plants. Evidence for a high glucose-phosphate-to-glucose turnover from in vivo steady-state and pulse-labeling experiments with [13C] glucose and [14C] glucose. Plant Physiol 138:2220-2232

Alves SC, Worland B, Thole V, Snape JW, Bevan MW, Vain P (2009) A protocol for agrobacterium-mediated transformation of brachypodium distachyon community standard line $\mathrm{Bd} 21$. Nat Protoc 4:638-649

Amudha J, Balasubramani G (2011) Recent molecular advances to cambat abiotic stress tolerance in crop plants. Biotech Mol Bio Rev 6:31-58

An GH, Lee S, Kim SH, Kim SR (2005) Molecular genetics using T-DNA in rice. Plant Cell Physiol 46:14-22

Arumuganathan K, Earle ED (1991) Nuclear DNA content of some important plant species. Plant Mol Biol Rep 9:208-218

Bansal M, Belcastro V, Ambesi-Impiombato A, di Bernardo D (2007) How to infer gene networks from expression profiles. Mol Syst Biol 3(1):78

Bartels D, Sunkar R (2005) Drought and salt tolerance in plants. Crit Rev Plant Sci 24:23-58

Battisti DS, Naylor RL (2009) Historical warnings of future food insecurity with unprecedented seasonal heat. Science 323:240-244

Becker J, Klopprogge C, Herold A, Zelder O, Bolten CJ, Wittmann C (2007) Metabolic flux engineering of L-lysine production in corynebacterium glutamicum: over expression and modification of G6P dehydrogenase. J Biotechnol 132:99-109

Berhan AM, Hulbert SH, Butler LG, Bennetzen JL (1993) Structure and evolution of the genomes of sorghum-bicolor and zea-mays. Theor Appl Genet 86:598-604

Berkman PJ, Skarshewski A, Lorenc MT, Lai K, Duran C, Ling EY, Stiller J, Smits L, Imelfort M, Manoli S, McKenzie M, Kubalakova M, Simkova H, Batley J, Fleury D, Dolezel J, Edwards D (2011) Sequencing and assembly of low copy and genic regions of isolated triticum aestivum chromosome arm 7DS. Plant Biotechnol J 9:768-775

Bino RJ, Hall RD, Fiehn O, Kopka J, Saito K, Draper J, Nikolau BJ, Mendes P, Roessner-Tunali U, Beale MH, Trethewey RN, Lange BM, Wurtele ES, Sumner LW (2004) Potential of metabolomics as a functional genomics tool. Trends Plant Sci 9:418-425

Boatright J, Negre F, Chen XL, Kish CM, Wood B, Peel G, Orlova I, Gang D, Rhodes D, Dudareva N (2004) Understanding in vivo benzenoid metabolism in petunia petal tissue. Plant Physiol 135:1993-2011

Bombarely A, Menda N, Tecle IY, Buels RM, Strickler S, Fischer-York T, Pujar A, Leto J, Gosselin J, Mueller LA (2011) The sol genomics network (solgenomics.net): growing tomatoes using perl. Nucleic Acids Res 39:D1149-D1155

Caldana C, Degenkolbe T, Cuadros-Inostroza A, Klie S, Sulpice R, Leisse A, Steinhauser D, Fernie AR, Willmitzer L, Hannah MA (2011) High-density kinetic analysis of the metabolomic and transcriptomic response of Arabidopsis to eight environmental conditions. Plant J 67:869-884

Canovas FM, Dumas-Gaudot E, Recorbet G, Jorrin J, Mock HP, Rossignol M (2004) Plant proteome analysis. Proteomics 4:285-298

Carrera J, Rodrigo G, Jaramillo A, Elena SF (2009) Reverse-engineering the Arabidopsis thaliana transcriptional network under changing environmental conditions. Genome biol 10(9):R96

Carro MS, Lim WK, Alvarez MJ, Bollo RJ, Zhao XD, Snyder EY, Sulman EP, Anne SL, Doetsch F, Colman H, Lasorella A, Aldape K, Califano A, Iavarone A (2010) The transcriptional network for mesenchymal transformation of brain tumours. Nature 463:318-368

Caruso G, Cavaliere C, Foglia P, Gubbiotti R, Samperi R, Lagana A (2009) Analysis of drought responsive proteins in wheat (Triticum durum) by 2D-PAGE and MALDI-TOF mass spectrometry. Plant Sci 177:570-576

Casati P, Morrow DJ, Fernandes JF, Walbot V (2011) Rapid Maize leaf and immature ear responses to UV-B radiation. Front Plant Sci 2:33 
Chantret N, Salse J, Sabot F, Rahman S, Bellec A, Laubin B, Dubois I, Dossat C, Sourdille P, Joudrier P, Gautier MF, Cattolico L, Beckert M, Aubourg S, Weissenbach J, Caboche M, Bernard M, Leroy P, Chalhoub B (2005) Molecular basis of evolutionary events that shaped the hardness locus in diploid and polyploid wheat species (Triticum and aegilops). Plant Cell 17:1033-1045

Charng YY, Liu HC, Liu NY, Hsu FC, Ko SS (2006) Arabidopsis Hsa32, a novel heat shock protein, is essential for acquired thermotolerance during long recovery after acclimation. Plant Physiol 140:1297-1305

Christensen B, Nielsen J (2000) Metabolic network analysis. A powerful tool in metabolic engineering. Adv Biochem Eng Biotechnol 66:209-231

Collins NC, Tardieu F, Tuberosa R (2008) Quantitative trait loci and crop performance under abiotic stress: where do we stand? Plant Physiol 147:469-486

Cook D, Fowler S, Fiehn O, Thomashow MF (2004) A prominent role for the CBF cold response pathway in configuring the low-temperature metabolome of Arabidopsis. Proc Natl Acad Sci USA 101:15243-15248

Craigon DJ, James N, Okyere J, Higgins J, Jotham J, May S (2004) NASCArrays: a repository for microarray data generated by NASC's transcriptomics service. Nucleic Acids Res 32:D575-D577

Cramer GR, Ergul A, Grimplet J, Tillett RL, Tattersall EAR, Bohlman MC, Vincent D, Sonderegger J, Evans J, Osborne C, Quilici D, Schlauch KA, Schooley DA, Cushman JC (2007) Water and salinity stress in grapevines: early and late changes in transcript and metabolite profiles. Funct Integr Genomics 7:111-134

Cramer GR, Urano K, Delrot S, Pezzotti M, Shinozaki K (2011) Effects of abiotic stress on plants: a systems biology perspective. BMC Plant Biol 11(1):63

de la Fuente A, Brazhnik P, Mendes P (2002) Linking the genes: inferring quantitative gene networks from microarray data. Trends Genet: TIG 18:395-398

de Vienne D, Leonardi A, Damerval C, Zivy M (1999) Genetics of proteome variation for QTL characterization: application to drought-stress responses in maize. J Exp Bot 50:303-309

Deeb F, van der Weele CM, Wolniak SM (2010) Spermidine is a morphogenetic determinant for cell fate specification in the male gametophyte of the water fern marsilea vestita. Plant Cell 22:3678-3691

Des Rosiers C, Lloyd S, Comte B, Chatham JC (2004) A critical perspective of the use of C-13isotopomer analysis by GCMS and NMR as applied to cardiac metabolism. Metab Eng 6:44-58

Deyholos MK (2010) Making the most of drought and salinity transcriptomics. Plant Cell Environ 33:648-654

Dieuaide-Noubhani M, Raffard G, Canioni P, Pradet A, Raymond P (1995) Quantification of compartmented metabolic fluxes in maize root tips using isotope distribution from 13C- or 14C-labeled glucose. J Biol Chem 270:13147-13159

Dixon RA, Strack D (2003) Phytochemistry meets genome analysis, and beyond. Phytochemistry 62:815-816

Dolezel J, Kubalakova M, Paux E, Bartos J, Feuillet C (2007) Chromosome-based genomics in the cereals. Chromosome Res: Int J Mol, Supramol Evol Aspects Chromosome Biol 15:51-66

Dooki AD, Mayer-Posner FJ, Askari H, Zaiee AA, Salekdeh GH (2006) Proteomic responses of rice young panicles to salinity. Proteomics 6:6498-6507

Druka A, Franckowiak J, Lundqvist U, Bonar N, Alexander J, Houston K, Radovic S, Shahinnia F, Vendramin V, Morgante M, Stein N, Waugh R (2011) Genetic dissection of barley morphology and development. Plant Physiol 155:617-627

Druka A, Muehlbauer G, Druka I, Caldo R, Baumann U, Rostoks N, Schreiber A, Wise R, Close T, Kleinhofs A, Graner A, Schulman A, Langridge P, Sato K, Hayes P, McNicol J, Marshall D, Waugh R (2006) An atlas of gene expression from seed to seed through barley development. Funct Integr Genomics 6:202-211 
Eastmond PJ, van Dijken AJH, Spielman M, Kerr A, Tissier AF, Dickinson HG, Jones JDG, Smeekens SC, Graham IA (2002) Trehalose-6-phosphate synthase 1, which catalyses the first step in trehalose synthesis, is essential for Arabidopsis embryo maturation. Plant J 29:225-235

Edwards D, Batley J (2010) Plant genome sequencing: applications for crop improvement. Plant Biotechnol J 8:2-9

Edwards S, Nguyen BT, Do B, Roberts JKM (1998) Contribution of malic enzyme, pyruvate kinase, phosphoenolpyruvate carboxylase, and the krebs cycle to respiration and biosynthesis and to intracellular $\mathrm{pH}$ regulation during hypoxia in maize root tips observed by nuclear magnetic resonance imaging and gas chromatography-mass spectrometry. Plant Physiol 116:1073-1081

Ergen NZ, Budak H (2009) Sequencing over 13,000 expressed sequence tags from six subtractive cDNA libraries of wild and modern wheats following slow drought stress. Plant Cell Environ 32:220-236

Ergen NZ, Thimmapuram J, Bohnert HJ, Budak H (2009) Transcriptome pathways unique to dehydration tolerant relatives of modern wheat. Funct Integr Genomics 9:377-396

Espinoza C, Degenkolbe T, Caldana C, Zuther E, Leisse A, Willmitzer L, Hincha DK, Hannah MA (2010) Interaction with diurnal and circadian regulation results in dynamic metabolic and transcriptional changes during cold acclimation in Arabidopsis. PloS one 5(11):e14101

Feist AM, Herrgard MJ, Thiele I, Reed JL, Palsson BO (2009) Reconstruction of biochemical networks in microorganisms. Nat Rev Microbiol 7:129-143

Feuillet C, Keller B (2002) Comparative genomics in the grass family: molecular characterization of grass genome structure and evolution. Ann Bot 89:3-10

Fiehn O (2002) Metabolomics: the link between genotypes and phenotypes. Plant Mol Biol 48:155-171

Filiz E, Ozdemir BS, Budak F, Vogel JP, Tuna M, Budak H (2009) Molecular, morphological, and cytological analysis of diverse Brachypodium distachyon inbred lines. Genome 52:876890 National Research Council Canada, Conseil National de Recherches Canada

Finkel E (2009) Imaging With 'phenomics', plant scientists hope to shift breeding into overdrive. Science 325:380-381

Finnie C, Melchior S, Roepstorff P, Svensson B (2002) Proteome analysis of grain filling and seed maturation in barley. Plant Physiol 129:1308-1319

Fleury D, Jefferies S, Kuchel H, Langridge P (2010) Genetic and genomic tools to improve drought tolerance in wheat. J Exp Bot 61:3211-3222

Frick O, Wittmann C (2005) Characterization of the metabolic shift between oxidative and fermentative growth in Saccharomyces cerevisiae by comparative C-13 flux analysis. Microb Cell Fact 4

Fujita M, Mizukado S, Fujita Y, Ichikawa T, Nakazawa M, Seki M, Matsui M, YamaguchiShinozaki K, Shinozaki K (2007) Identification of stress-tolerance-related transcriptionfactor genes via mini-scale Full-length cDNA Over-eXpressor (FOX) gene hunting system. Biochem Bioph Res Co 364:250-257

Furbank RT, Tester M (2011) Phenomics: technologies to relieve the phenotyping bottleneck. Trends Plant Sci 16:635-644

Gagneul D, Ainouche A, Duhaze C, Lugan R, Larher FR, Bouchereau A (2007) A reassessment of the function of the so-called compatible solutes in the halophytic Plumbaginaceae Limonium latifolium. Plant Physiol 144:1598-1611

Garvin DF, McKenzie N, Vogel JP, Mockler TC, Blankenheim ZJ, Wright J, Cheema JJS, Dicks J, Huo NX, Hayden DM, Gu Y, Tobias C, Chang JH, Chu A, Trick M, Michael TP, Bevan MW, Snape JW (2010) An SSR-based genetic linkage map of the model grass Brachypodium distachyon. Genome 53:1-13 National Research Council Canada, Conseil National de Recherches Canada

Geu-Flores F, Nielsen MT, Nafisi M, Moldrup ME, Olsen CE, Motawia MS, Halkier BA (2009) Glucosinolate engineering identifies a gamma-glutamyl peptidase. Nat Chem Biol 5:575-577 
Gibon Y, Usadel B, Blaesing OE, Kamlage B, Hoehne M, Trethewey R, Stitt M (2006) Integration of metabolite with transcript and enzyme activity profiling during diurnal cycles in Arabidopsis rosettes. Genome Biol 7:R76

Glawischnig E, Gierl A, Tomas A, Bacher A, Eisenreich W (2001) Retrobiosynthetic nuclear magnetic resonance analysis of amino acid biosynthesis and intermediary metabolism. Metabolic flux in developing maize kernels. Plant Physiol 125:1178-1186

Glawischnig E, Gierl A, Tomas A, Bacher A, Eisenreich W (2002) Starch biosynthesis and intermediary metabolism in maize kernels. Quantitative analysis of metabolite flux by nuclear magnetic resonance. Plant Physiol 130:1717-1727

Goda H, Sasaki E, Akiyama K, Maruyama-Nakashita A, Nakabayashi K, Li WQ, Ogawa M, Yamauchi Y, Preston J, Aoki K, Kiba T, Takatsuto S, Fujioka S, Asami T, Nakano T, Kato H, Mizuno T, Sakakibara H, Yamaguchi S, Nambara E, Kamiya Y, Takahashi H, Hirai MY, Sakurai T, Shinozaki K, Saito K, Yoshida S, Shimada Y (2008) The AtGenExpress hormone and chemical treatment data set: experimental design, data evaluation, model data analysis and data access. Plant J 55:526-542

Goff SA, Ricke D, Lan TH, Presting G, Wang RL, Dunn M, Glazebrook J, Sessions A, Oeller P, Varma H, Hadley D, Hutchinson D, Martin C, Katagiri F, Lange BM, Moughamer T, Xia Y, Budworth P, Zhong JP, Miguel T, Paszkowski U, Zhang SP, Colbert M, Sun WL, Chen LL, Cooper B, Park S, Wood TC, Mao L, Quail P, Wing R, Dean R, Yu YS, Zharkikh A, Shen R, Sahasrabudhe S, Thomas A, Cannings R, Gutin A, Pruss D, Reid J, Tavtigian S, Mitchell J, Eldredge G, Scholl T, Miller RM, Bhatnagar S, Adey N, Rubano T, Tusneem N, Robinson R, Feldhaus J, Macalma T, Oliphant A, Briggs S (2002) A draft sequence of the rice genome (Oryza sativa L. ssp japonica). Science 296:92-100

Gomez-Porras JL, Riano-Pachon DM, Dreyer I, Mayer JE, Mueller-Roeber B (2007) Genomewide analysis of ABA-responsive elements ABRE and CE3 reveals divergent patterns in Arabidopsis and rice. BMC Genomics 8(1):260

Gong QQ, Li PH, Ma SS, Rupassara SI, Bohnert HJ (2005) Salinity stress adaptation competence in the extremophile Thellungiella halophila in comparison with its relative Arabidopsis thaliana. Plant J 44:826-839

Grafahrend-Belau E, Schreiber F, Koschutzki D, Junker BH (2009) Flux balance analysis of barley seeds: a computational approach to study systemic properties of central metabolism. Plant Physiol 149:585-598

Gu YQ, Ma YQ, Huo NX, Vogel JP, You FM, Lazo GR, Nelson WM, Soderlund C, Dvorak J, Anderson OD, Luo MC (2009) A BAC-based physical map of Brachypodium distachyon and its comparative analysis with rice and wheat. BMC Genomics 10(1):496

Gupta AK, Kaur N (2005) Sugar signalling and gene expression in relation to carbohydrate metabolism under abiotic stresses in plants. J Biosciences 30:761-776

Gupta PK, Mir RR, Mohan A, Kumar J (2008) Wheat genomics: present status and future prospects. Int J Plant Genomics 2008:896451

Gygi SP, Rist B, Gerber SA, Turecek F, Gelb MH, Aebersold R (1999) Quantitative analysis of complex protein mixtures using isotope-coded affinity tags. Nat Biotechnol 17:994-999

Haberer G, Young S, Bharti AK, Gundlach H, Raymond C, Fuks G, Butler E, Wing RA, Rounsley S, Birren B, Nusbaum C, Mayer KF, Messing J (2005) Structure and architecture of the maize genome. Plant Physiol 139:1612-1624

Hache H, Lehrach H, Herwig R (2009) Reverse engineering of gene regulatory networks: a comparative study. EURASIP J Bioinf Syst Biol 2009:8

Hadiarto T, Tran LS (2011) Progress studies of drought-responsive genes in rice. Plant Cell Rep 30:297-310

Hagel JM, Facchini PJ (2008) Plant metabolomics: analytical platforms and integration with functional genomics. Phytochem Rev 7:479-497

Hajheidari M, Eivazi A, Buchanan BB, Wong JH, Majidi I, Salekdeh GH (2007) Proteomics uncovers a role for redox in drought tolerance in wheat. J Proteome Res 6:1451-1460

Hall RD (2006) Plant metabolomics: from holistic hope, to hype, to hot topic. New Phytol $169: 453-468$ 
Hamada K, Hongo K, Suwabe K, Shimizu A, Nagayama T, Abe R, Kikuchi S, Yamamoto N, Fujii T, Yokoyama K, Tsuchida H, Sano K, Mochizuki T, Oki N, Horiuchi Y, Fujita M, Watanabe M, Matsuoka M, Kurata N, Yano K (2011) OryzaExpress: an integrated database of gene expression networks and omics annotations in rice. Plant Cell Physiol 52:220-229

Hansen BG, Kliebenstein DJ, Halkier BA (2007) Identification of a flavin-monooxygenase as the S-oxygenating enzyme in aliphatic glucosinolate biosynthesis in Arabidopsis. Plant $\mathrm{J}$ 50:902-910

Hanzawa Y, Takahashi T, Michael AJ, Burtin D, Long D, Pineiro M, Coupland G, Komeda Y (2000) ACAULIS5 an Arabidopsis gene required for stem elongation, encodes a spermine synthase. EMBO J 19:4248-4256

Harrigan GG, Stork LG, Riordan SG, Ridley WP, Macisaac S, Halls SC, Orth R, Rau D, Smith RG, Wen L, Brown WE, Riley R, Sun D, Modiano S, Pester T, Lund A, Nelson D (2007) Metabolite analyses of grain from maize hybrids grown in the United States under drought and watered conditions during the 2002 field season. J Agric Food Chem 55:6169-6176

Hasegawa PM, Bressan RA, Zhu JK, Bohnert HJ (2000) Plant cellular and molecular responses to high salinity. Ann Rev Plant Physiol Plant Mol Biol 51:463-499

Hayes PM, Castro A, Marquez-Cedillo L, Corey A, Henson C, Jones B, Kling J, Mather D, Matus I, Rossi C, Sato K (2003) Genetic diversity for quantitatively inherited agronomic and malting quality traits. In: Von Bothmer R, Knupfeer H, van Hintum T, Sato K (eds) Diversity barley. Elsevier Science Publishers, Amsterdam

Helmy M, Tomita M, Ishihama Y (2011) OryzaPG-DB: rice proteome database based on shotgun proteogenomics. BMC Plant Biol 11:63

Hirai MY, Sugiyama K, Sawada Y, Tohge T, Obayashi T, Suzuki A, Araki R, Sakurai N, Suzuki H, Aoki K, Goda H, Nishizawa OI, Shibata D, Saito K (2007) Omics-based identification of Arabidopsis Myb transcription factors regulating aliphatic glucosinolate biosynthesis. Proc Natl Acad Sci USA 104:6478-6483

Hirai MY, Yano M, Goodenowe DB, Kanaya S, Kimura T, Awazuhara M, Arita M, Fujiwara T, Saito K (2004) Integration of transcriptomics and metabolomics for understanding of global responses to nutritional stresses in Arabidopsis thaliana. Proc Natl Acad Sci USA 101:10205-10210

Horan K, Jang C, Bailey-Serres J, Mittler R, Shelton C, Harper JF, Zhu JK, Cushman JC, Gollery M, Girke T (2008) Annotating genes of known and unknown function by large-scale coexpression analysis. Plant Physiol 147:41-57

Hu WH, Hu GC, Han B (2009) Genome-wide survey and expression profiling of heat shock proteins and heat shock factors revealed overlapped and stress specific response under abiotic stresses in rice. Plant Sci 176:583-590

Huo CM, Zhao BC, Ge RC, Shen YZ, Huang ZJ (2004) Proteomic analysis of the salt tolerance mutant of wheat under salt stress. Acta Genetica Sinica 31:1408-1414 Yi chuan xue bao

Huo NX, Gu YQ, Lazo GR, Vogel JP, Coleman-Derr D, Luo MC, Thilmony R, Garvin DF, Anderson OD (2006) Construction and characterization of two BAC libraries from Brachypodium distachyon, a new model for grass genomics. Genome 49(9):1099-1108 National Research Council Canada, Conseil National de Recherches Canada

Huo NX, Lazo GR, Vogel JP, You FM, Ma YQ, Hayde DM, Coleman-Derr D, Hill TA, Dvorak J, Anderson OD, Luo MC, Gu YQ (2008) The nuclear genome of Brachypodium distachyon: analysis of BAC end sequences. Funct Integr Genomics 8:135-147

Imai A, Matsuyama T, Hanzawa Y, Akiyama T, Tamaoki M, Saji H, Shirano Y, Kato T, Hayashi H, Shibata D, Tabata S, Komeda Y, Takahashi T (2004) Spermidine synthase genes are essential for survival of Arabidopsis. Plant Physiol 135:1565-1573

Ingram J, Bartels D (1996) The molecular basis of dehydration tolerance in plants. Ann Rev Plant Physiol Plant Mol Biol 47:377-403

Intergovernmental Panel on Climate Change (IPCC) (2007) In: Pachauri RK, Reisinger A (eds) Climate change 2007 synthesis report. IPCC, Geneva

Izawa T, Mihara M, Suzuki Y, Gupta M, Itoh H, Nagano AJ, Motoyama R, Sawada Y, Yano M, Hirai MY, Makino A, Nagamura Y (2011) Os-GIGANTEA confers robust diurnal rhythms on the global transcriptome of rice in the field. Plant Cell 23:1741-1755 
Janz D, Behnke K, Schnitzler JP, Kanawati B, Schmitt-Kopplin P, Polle A (2010) Pathway analysis of the transcriptome and metabolome of salt sensitive and tolerant poplar species reveals evolutionary adaption of stress tolerance mechanisms. BMC Plant Biol 10:150

Jeanneau M, Gerentes D, Foueillassar X, Zivy M, Vidal J, Toppan A, Perez P (2002) Improvement of drought tolerance in maize: towards the functional validation of the $\mathrm{Zm}$ Asr1 gene and increase of water use efficiency by over-expressing C4-PEPC. Biochimie 84:1127-1135

Jordan KW, Nordenstam J, Lauwers GY, Rothenberger DA, Alavi K, Garwood M, Cheng LL (2009) Metabolomic characterization of human rectal adenocarcinoma with intact tissue magnetic resonance spectroscopy. Dis Colon Rectum 52:520-525

Kaplan F, Kopka J, Haskell DW, Zhao W, Schiller KC, Gatzke N, Sung DY, Guy CL (2004) Exploring the temperature-stress metabolome of Arabidopsis. Plant Physiol 136:4159-4168

Kaplan F, Kopka J, Sung DY, Zhao W, Popp M, Porat R, Guy CL (2007) Transcript and metabolite profiling during cold acclimation of Arabidopsis reveals an intricate relationship of cold-regulated gene expression with modifications in metabolite content. Plant $\mathbf{J}$ 50:967-981

Kell DB, Brown M, Davey HM, Dunn WB, Spasic I, Oliver SG (2005) Metabolic footprinting and systems biology: the medium is the message. Nat Rev Microbiol 3:557-565

Kempa S, Krasensky J, Dal Santo S, Kopka J, Jonak C (2008) A central role of abscisic acid in stress-regulated carbohydrate metabolism. PLoS ONE 3:e3935

Kempa S, Rozhon W, Samaj J, Erban A, Baluska F, Becker T, Haselmayer J, Schleiff E, Kopka J, Hirt H, Jonak C (2007) A plastid-localized glycogen synthase kinase 3 modulates stress tolerance and carbohydrate metabolism. Plant J 49:1076-1090

Kholodenko BN, Kiyatkin A, Bruggeman FJ, Sontag E, Westerhoff HV, Hoek JB (2002) Untangling the wires: a strategy to trace functional interactions in signaling and gene networks. Proc Natl Acad Sci USA 99:12841-12846

Kiba T, Kudo T, Kojima M, Sakakibara H (2011) Hormonal control of nitrogen acquisition: roles of auxin, abscisic acid, and cytokinin. J Exp Bot 62:1399-1409

Kiefer P, Heinzle E, Zelder O, Wittmann C (2004) Comparative metabolic flux analysis of lysineproducing Corynebacterium glutamicum cultured on glucose or fructose. Appl Environ Microbiol 70:229-239

Kim ST, Cho KS, Yu S, Kim SG, Hong JC, Han CD, Bae DW, Nam MH, Kang KY (2003) Proteomic analysis of differentially expressed proteins induced by rice blast fungus and elicitor in suspension-cultured rice cells. Proteomics 3:2368-2378

Kimura M, Yamamoto YY, Seki M, Sakurai T, Sato M, Abe T, Yoshida S, Manabe K, Shinozaki K, Matsui M (2003) Identification of Arabidopsis genes regulated by high light-stress using cDNA microarray. Photochem Photobiol 77:226-233

Kishor PBK, Sangam S, Amrutha RN, Laxmi PS, Naidu KR, Rao KRSS, Rao S, Reddy KJ, Theriappan P, Sreenivasulu N (2005) Regulation of proline biosynthesis, degradation, uptake and transport in higher plants: Its implications in plant growth and abiotic stress tolerance. Curr Sci India 88:424-438

Kitano H (2000) Perspectives on systems biology. New Generat Comput 18:199-216

Kogel KH, Voll LM, Schafer P, Jansen C, Wu YC, Langen G, Imani J, Hofmann J, Schmiedl A, Sonnewald S, von Wettstein D, Cook RJ, Sonnewald U (2010) Transcriptome and metabolome profiling of field-grown transgenic barley lack induced differences but show cultivarspecific variances. Proc Natl Acad Sci USA 107:6198-6203

Kohli A, Narciso JO, Miro B, Raorane M (2012) Root proteases: reinforced links between nitrogen uptake and mobilization and drought tolerance. Physiol Plant 145:165-179

Komatsu S, Yano H (2006) Update and challenges on proteomics in rice. Proteomics 6:4057-4068

Kondou Y, Higuchi M, Takahashi S, Sakurai T, Ichikawa T, Kuroda H, Yoshizumi T, Tsumoto Y, Horii Y, Kawashima M, Hasegawa Y, Kuriyama T, Matsui K, Kusano M, Albinsky D, Takahashi H, Nakamura Y, Suzuki M, Sakakibara H, Kojima M, Akiyama K, Kurotani A, Seki M, Fujita M, Enju A, Yokotani N, Saitou T, Ashidate K, Fujimoto N, Ishikawa Y, Mori Y, Nanba R, Takata K, Uno K, Sugano S, Natsuki J, Dubouzet JG, Maeda S, Ohtake M, 
Mori M, Oda K, Takatsuji H, Hirochika H, Matsui M (2009) Systematic approaches to using the FOX hunting system to identify useful rice genes. Plant J 57:883-894

Koornneef M, AlonsoBlanco C, Peeters AJM (1997) Genetic approaches in plant physiology. New Phytol 137:1-8

Kremling A, Fischer S, Gadkar K, Doyle FJ, Sauter T, Bullinger E, Allgower F, Gilles ED (2004) A benchmark for methods in reverse engineering and model discrimination: Problem formulation and solutions. Genome Res 14:1773-1785

Kreps JA, Wu Y, Chang HS, Zhu T, Wang X, Harper JF (2002) Transcriptome changes for Arabidopsis in response to salt, osmotic, and cold stress. Plant Physiol 130:2129-2141

Krishnan A, Guiderdoni E, An G, Hsing YIC, Han CD, Lee MC, Yu SM, Upadhyaya N, Ramachandran S, Zhang QF, Sundaresan V, Hirochika H, Leung H, Pereira A (2009) Mutant resources in rice for functional genomics of the grasses. Plant Physiol 149:165-170

Kruger NJ, Le Lay P, Ratcliffe RG (2007) Vacuolar compartmentation complicates the steadystate analysis of glucose metabolism and forces reappraisal of sucrose cycling in plants. Phytochemistry 68:2189-2196

Kumar CS, Wing RA, Sundaresan V (2005) Efficient insertional mutagenesis in rice using the maize En/Spm elements. Plant J 44:879-892

Kuromori T, Takahashi S, Kondou Y, Shinozaki K, Matsui M (2009) phenome analysis in plant species using loss-of-function and gain-of-function mutants. Plant Cell Physiol 50:1215-1231

Larkindale J, Vierling E (2008) Core genome responses involved in acclimation to high temperature. Plant Physiol 146:748-761

Lee TH, Kim YK, Pham TT, Song SI, Kim JK, Kang KY, An G, Jung KH, Galbraith DW, Kim M, Yoon UH, Nahm BH (2009) RiceArrayNet: a database for correlating gene expression from transcriptome profiling, and its application to the analysis of coexpressed genes in rice. Plant Physiol 151:16-33

Li Y, Shrestha B, Vertes A (2008) Atmospheric pressure infrared MALDI imaging mass spectrometry for plant metabolomics. Anal Chem 80:407-420

Lim CJ, Yang KA, Hong JK, Choi JS, Yun DJ, Hong JC, Chung WS, Lee SY, Cho MJ, Lim CO (2006) Gene expression profiles during heat acclimation in Arabidopsis thaliana suspensionculture cells. J Plant Res 119:373-383

Lugan R, Niogret MF, Leport L, Guegan JP, Larher FR, Savoure A, Kopka J, Bouchereau A (2010) Metabolome and water homeostasis analysis of Thellungiella salsuginea suggests that dehydration tolerance is a key response to osmotic stress in this halophyte. Plant $\mathbf{J}$ 64:215-229

Majoul T, Bancel E, Triboi E, Ben Hamida J, Branlard G (2003) Proteomic analysis of the effect of heat stress on hexaploid wheat grain: characterization of heat-responsive proteins from total endosperm. Proteomics 3:175-183

Majoul T, Bancel E, Triboi E, Ben Hamida J, Branlard G (2004) Proteomic analysis of the effect of heat stress on hexaploid wheat grain: characterization of heat-responsive proteins from non-prolamins fraction. Proteomics 4:505-513

Marbach D, Prill RJ, Schaffter T, Mattiussi C, Floreano D, Stolovitzky G (2010) Revealing strengths and weaknesses of methods for gene network inference. Proc Natl Acad Sci USA 107:6286-6291

Masoudi-Nejad A, Goto S, Jauregui R, Ito M, Kawashima S, Moriya Y, Endo TR, Kanehisa M (2007) EGENES: transcriptome-based plant database of genes with metabolic pathway information and expressed sequence tag indices in KEGG. Plant Physiol 144:857-866

Matsuda F, Morino K, Ano R, Kuzawa M, Wakasa K, Miyagawa H (2005) Metabolic flux analysis of the phenylpropanoid pathway in elicitor-treated potato tuber tissue. Plant Cell Physiol 46:454-466

Matsuda F, Shinbo Y, Oikawa A, Hirai MY, Fiehn O, Kanaya S, Saito K (2009) Assessment of metabolome annotation quality: a method for evaluating the false discovery rate of elemental composition searches. PloS One 4(10):e7490 
Mattioli R, Falasca G, Sabatini S, Altamura MM, Costantino P, Trovato M (2009) The proline biosynthetic genes P5CS1 and P5CS2 play overlapping roles in Arabidopsis flower transition but not in embryo development. Physiol Plant 137:72-85

Mattioli R, Marchese D, D’Angeli S, Altamura MM, Costantino P, Trovato M (2008) Modulation of intracellular proline levels affects flowering time and inflorescence architecture in Arabidopsis. Plant Mol Biol 66:277-288

Mayer KF, Martis M, Hedley PE, Simkova H, Liu H, Morris JA, Steuernagel B, Taudien S, Roessner S, Gundlach H, Kubalakova M, Suchankova P, Murat F, Felder M, Nussbaumer T, Graner A, Salse J, Endo T, Sakai H, Tanaka T, Itoh T, Sato K, Platzer M, Matsumoto T, Scholz U, Dolezel J, Waugh R, Stein N (2011) Unlocking the barley genome by chromosomal and comparative genomics. Plant Cell 23:1249-1263

Mechin V, Balliau T, Chateau-Joubert S, Davanture M, Langella O, Negroni L, Prioul JL, Thevenot C, Zivy M, Damerval C (2004) A two-dimensional proteome map of maize endosperm. Phytochemistry 65:1609-1618

Mir RR, Zaman-Allah M, Sreenivasulu N, Trethowan R, Varshney RK (2012) Integrated genomics, physiology and breeding approaches for improving drought tolerance in crops. Theor Appl Genet 125:625-645

Mittler R (2006) Abiotic stress, the field environment and stress combination. Trends Plant Sci 11:15-19

Miyao A, Iwasaki Y, Kitano H, Itoh J, Maekawa M, Murata K, Yatou O, Nagato Y, Hirochika H (2007) A large-scale collection of phenotypic data describing an insertional mutant population to facilitate functional analysis of rice genes. Plant Mol Biol 63:625-635

Mochida K, Uehara-Yamaguchi Y, Yoshida T, Sakurai T, Shinozaki K (2011) Global landscape of a co-expressed gene network in barley and its application to gene discovery in triticeae crops. Plant Cell Physiol 52:785-803

Mohammadi M, Kav NN, Deyholos MK (2007) Transcriptional profiling of hexaploid wheat (Triticum aestivum L.) roots identifies novel, dehydration-responsive genes. Plant Cell Environ 30:630-645

Moles CG, Mendes P, Banga JR (2003) Parameter estimation in biochemical pathways: a comparison of global optimization methods. Genome Res 13:2467-2474

Montero-Barrientos M, Hermosa R, Cardoza RE, Gutierrez S, Nicolas C, Monte E (2010) Transgenic expression of the Trichoderma harzianum hsp70 gene increases Arabidopsis resistance to heat and other abiotic stresses. J Plant Physiol 167:659-665

Mullarkey M, Jones P (2000) Isolation and analysis of thermotolerant mutants of wheat. J Exp Bot 51:139-146

Mutwil M, Klie S, Tohge T, Giorgi FM, Wilkins O, Campbell MM, Fernie AR, Usadel B, Nikoloski Z, Persson S (2011) PlaNet: combined sequence and expression comparisons across plant networks derived from seven species. Plant Cell 23:895-910

Nakagami H, Sugiyama N, Ishihama Y, Shirasu K (2012) Shotguns in the front line: phosphoproteomics in plants. Plant Cell Physiol 53:118-124

Nakagami H, Sugiyama N, Mochida K, Daudi A, Yoshida Y, Toyoda T, Tomita M, Ishihama Y, Shirasu K (2010) Large-scale comparative phosphoproteomics identifies conserved phosphorylation sites in plants. Plant Physiol 153:1161-1174

Needham CJ, Manfield IW, Bulpitt AJ, Gilmartin PM, Westhead DR (2009) From gene expression to gene regulatory networks in Arabidopsis thaliana. BMC Syst Biol 3(1):85

Nishiyama R, Watanabe Y, Fujita Y, Le DT, Kojima M, Werner T, Vankova R, YamaguchiShinozaki K, Shinozaki K, Kakimoto T, Sakakibara H, Schmulling T, Tran LS (2011) Analysis of cytokinin mutants and regulation of cytokinin metabolic genes reveals important regulatory roles of cytokinins in drought, salt and abscisic acid responses, and abscisic acid biosynthesis. Plant Cell 23:2169-2183

Obayashi T, Kinoshita K, Nakai K, Shibaoka M, Hayashi S, Saeki M, Shibata D, Saito K, Ohta H (2007) ATTED-II: a database of co-expressed genes and cis elements for identifying coregulated gene groups in Arabidopsis. Nucleic Acids Res 35:D863-D869 
Obayashi T, Nishida K, Kasahara K, Kinoshita K (2011) ATTED-II updates: condition-specific gene coexpression to extend coexpression analyses and applications to a broad range of flowering plants. Plant Cell Physiol 52:213-219

Okazaki Y, Shimojima M, Sawada Y, Toyooka K, Narisawa T, Mochida K, Tanaka H, Matsuda F, Hirai A, Hirai MY, Ohta H, Saito K (2009) A chloroplastic UDP-glucose pyrophosphorylase from arabidopsis is the committed enzyme for the first step of sulfolipid biosynthesis. Plant Cell 21:892-909

Oksman-Caldentey KM, Saito K (2005) Integrating genomics and metabolomics for engineering plant metabolic pathways. Curr Opin Biotechnol 16:174-179

Oliver SG, Winson MK, Kell DB, Baganz F (1998) Systematic functional analysis of the yeast genome. Trends Biotechnol 16:373-378

O'Malley RC, Ecker JR (2010) Linking genotype to phenotype using the Arabidopsis unimutant collection. Plant J 61:928-940

Oono Y, Seki M, Nanjo T, Narusaka M, Fujita M, Satoh R, Satou M, Sakurai T, Ishida J, Akiyama K, Iida K, Maruyama K, Satoh S, Yamaguchi-Shinozaki K, Shinozaki K (2003) Monitoring expression profiles of Arabidopsis gene expression during rehydration process after dehydration using ca 7000 full-length cDNA microarray. Plant J: Cell Mol Biol 34:868-887

Osuna D, Usadel B, Morcuende R, Gibon Y, Blasing OE, Hohne M, Gunter M, Kamlage B, Trethewey R, Scheible WR, Stitt M (2007) Temporal responses of transcripts, enzyme activities and metabolites after adding sucrose to carbon-deprived Arabidopsis seedlings. Plant $\mathrm{J}$ 49:463-491

Palanivelu R, Brass L, Edlund AF, Preuss D (2003) Pollen tube growth and guidance is regulated by POP2, an Arabidopsis gene that controls GABA levels. Cell 114:47-59

Pasam RK, Sharma R, Malosetti M, van Eeuwijk FA, Haseneyer G, Kilian B, Graner A (2012) Genome-wide association studies for agronomical traits in a world wide spring barley collection. BMC Plant Biol 12:16

Paterson AH, Bowers JE, Bruggmann R, Dubchak I, Grimwood J, Gundlach H, Haberer G, Hellsten U, Mitros T, Poliakov A, Schmutz J, Spannagl M, Tang H, Wang X, Wicker T, Bharti AK, Chapman J, Feltus FA, Gowik U, Grigoriev IV, Lyons E, Maher CA, Martis M, Narechania A, Otillar RP, Penning BW, Salamov AA, Wang Y, Zhang L, Carpita NC, Freeling M, Gingle AR, Hash CT, Keller B, Klein P, Kresovich S, McCann MC, Ming R, Peterson DG, Mehboobur R, Ware D, Westhoff P, Mayer KF, Messing J, Rokhsar DS (2009) The Sorghum bicolor genome and the diversification of grasses. Nature 457:551-556

Paux E, Sourdille P, Salse J, Saintenac C, Choulet F, Leroy P, Korol A, Michalak M, Kianian S, Spielmeyer W, Lagudah E, Somers D, Kilian A, Alaux M, Vautrin S, Berges H, Eversole K, Appels R, Safar J, Simkova H, Dolezel J, Bernard M, Feuillet C (2008) A physical map of the 1-gigabase bread wheat chromosome 3B. Science 322:101-104

Peleg Z, Blumwald E (2011) Hormone balance and abiotic stress tolerance in crop plants. Curr Opin Plant Biol 14:290-295

Peleg Z, Reguera M, Tumimbang E, Walia H, Blumwald E (2011) Cytokinin-mediated source/ sink modifications improve drought tolerance and increase grain yield in rice under waterstress. Plant Biotechnol J 9:747-758

Pennisi E (2008) Plant genetics: the blue revolution, drop by drop, gene by gene. Science 320:171-173

Persson S, Wei HR, Milne J, Page GP, Somerville CR (2005) Identification of genes required for cellulose synthesis by regression analysis of public microarray data sets. Proc Natl Acad Sci USA 102:8633-8638

Pinheiro C, Chaves MM (2011) Photosynthesis and drought: can we make metabolic connections from available data? J Exp Bot 62:869-882

Qureshi MI, Qadir S, Zolla L (2007) Proteomics-based dissection of stress-responsive pathways in plants. J Plant Physiol 164:1239-1260

Rabbani MA, Maruyama K, Abe H, Khan MA, Katsura K, Ito Y, Yoshiwara K, Seki M, Shinozaki K, Yamaguchi-Shinozaki K (2003) Monitoring expression profiles of rice genes 
under cold, drought, and high-salinity stresses and abscisic acid application using cDNA microarray and RNA gel-blot analyses. Plant Physiol 133:1755-1767

Rajendran K, Tester M, Roy SJ (2009) Quantifying the three main components of salinity tolerance in cereals. Plant Cell Environ 32:237-249

Ratcliffe RG, Shachar-Hill Y (2006) Measuring multiple fluxes through plant metabolic networks. Plant J 45:490-511

Reynolds TL, Nemeth MA, Glenn KC, Ridley WP, Astwood JD (2005) Natural variability of metabolites in maize grain: differences due to genetic background. J Agric Food Chem 53:10061-10067

Riccardi F, Gazeau P, de Vienne D, Zivy M (1998) Protein changes in response to progressive water deficit in maize. Quantitative variation and polypeptide identification. Plant Physiol 117:1253-1263

Rizhsky L, Liang HJ, Shuman J, Shulaev V, Davletova S, Mittler R (2004) When defense pathways collide. The response of Arabidopsis to a combination of drought and heat stress. Plant Physiol 134:1683-1696

Rohlig RM, Eder J, Engel KH (2009) Metabolite profiling of maize grain: differentiation due to genetics and environment. Metabolomics 5:459-477

Rolletschek H, Melkus G, Grafahrend-Belau E, Fuchs J, Heinzel N, Schreiber F, Jakob PM, Borisjuk L (2011) Combined noninvasive imaging and modeling approaches reveal metabolic compartmentation in the barley endosperm. Plant Cell 23:3041-3054

Roscher A, Kruger NJ, Ratcliffe RG (2000) Strategies for metabolic flux analysis in plants using isotope labelling. J Biotechnol 77:81-102

Rossel JB, Wilson IW, Pogson BJ (2002) Global changes in gene expression in response to high light in Arabidopsis. Plant Physiol 130:1109-1120

Rostoks N, Mudie S, Cardle L, Russell J, Ramsay L, Booth A, Svensson JT, Wanamaker SI, Walia H, Rodriguez EM, Hedley PE, Liu H, Morris J, Close TJ, Marshall DF, Waugh R (2005) Genome-wide SNP discovery and linkage analysis in barley based on genes responsive to abiotic stress. Mol Genet Genomics 274:515-527

Royal Society (2009) Reaping the benefits: science and the sustainable intensification of global agriculture. London (The Royal Society; Policy Document 11/09)

Safar J, Bartos J, Janda J, Bellec A, Kubalakova M, Valarik M, Pateyron S, Weiserova J, Tuskova R, Cihalikova J, Vrana J, Simkova H, Faivre-Rampant P, Sourdille P, Caboche M, Bernard M, Dolezel J, Chalhoub B (2004) Dissecting large and complex genomes: flow sorting and BAC cloning of individual chromosomes from bread wheat. Plant J: Cell Mol Biol 39:960-968

Safar J, Simkova H, Kubalakova M, Cihalikova J, Suchankova P, Bartos J, Dolezel J (2010) Development of chromosome-specific BAC resources for genomics of bread wheat. Cytogenet Genome Res 129:211-223

Saisho D, Takeda K (2011) Barley: emergence as a new research material of crop science. Plant Cell Physiol 52:724-727

Saito K, Hirai MY, Yonekura-Sakakibara K (2008) Decoding genes with coexpression networks and metabolomics: 'majority report by precogs'. Trends Plant Sci 13:36-43

Sakurai T, Kondou Y, Akiyama K, Kurotani A, Higuchi M, Ichikawa T, Kuroda H, Kusano M, Mori M, Saitou T, Sakakibara H, Sugano S, Suzuki M, Takahashi H, Takahashi S, Takatsuji H, Yokotani N, Yoshizumi T, Saito K, Shinozaki K, Oda K, Hirochika H, Matsui M (2011) RiceFOX: a database of Arabidopsis mutant lines overexpressing rice full-length cDNA that contains a wide range of trait information to facilitate analysis of gene function. Plant Cell Physiol 52:265-273

Salekdeh GH, Siopongco J, Wade LJ, Ghareyazie B, Bennett J (2002) Proteomic analysis of rice leaves during drought stress and recovery. Proteomics 2:1131-1145

Samach A, Onouchi H, Gold SE, Ditta GS, Schwarz-Sommer Z, Yanofsky MF, Coupland G (2000) Distinct roles of CONSTANS target genes in reproductive development of Arabidopsis. Science 288:1613-1616

Sanchez DH, Siahpoosh MR, Roessner U, Udvardi M, Kopka J (2008) Plant metabolomics reveals conserved and divergent metabolic responses to salinity. Physiol Plant 132:209-219 
Sangam S, Jayasree D, Reddy KJ, Chari PVB, Sreenivasulu N, Kavi Kishor PB (2005) Salt tolerance in plants-transgenic approaches. J Plant Biotechnol. 7:1-15

SanMiguel P, Gaut BS, Tikhonov A, Nakajima Y, Bennetzen JL (1998) The paleontology of intergene retrotransposons of maize. Nat Genet 20:43-45

Sato S, Arita M, Soga T, Nishioka T, Tomita M (2008) Time-resolved metabolomics reveals metabolic modulation in rice foliage. BMC Syst Biol 2(1):51

Satoh-Nagasawa N, Nagasawa N, Malcomber S, Sakai H, Jackson D (2006) A trehalose metabolic enzyme controls inflorescence architecture in maize. Nature 441:227-230

Sauer U, Lasko DR, Fiaux J, Hochuli M, Glaser R, Szyperski T, Wuthrich K, Bailey JE (1999) Metabolic flux ratio analysis of genetic and environmental modulations of Escherichia coli central carbon metabolism. J Bacteriol 181:6679-6688

Sawada Y, Akiyama K, Sakata A, Kuwahara A, Otsuki H, Sakurai T, Saito K, Hirai MY (2009) Widely targeted metabolomics based on large-scale MS/MS data for elucidating metabolite accumulation patterns in plants. Plant Cell Physiol 50:37-47

Schaeffer ML, Harper LC, Gardiner JM, Andorf CM, Campbell DA, Cannon EKS, Sen TZ, Lawrence CJ (2011) MaizeGDB: curation and outreach go hand-in-hand. Database-Oxford

Schauer N, Fernie AR (2006) Plant metabolomics: towards biological function and mechanism. Trends Plant Sci 11:508-516

Schmid M, Davison TS, Henz SR, Pape UJ, Demar M, Vingron M, Scholkopf B, Weigel D, Lohmann JU (2005) A gene expression map of Arabidopsis thaliana development. Nat Genet 37:501-506

Schnable PS, Ware D, Fulton RS, Stein JC, Wei F, Pasternak S, Liang C, Zhang J, Fulton L, Graves TA, Minx P, Reily AD, Courtney L, Kruchowski SS, Tomlinson C, Strong C, Delehaunty K, Fronick C, Courtney B, Rock SM, Belter E, Du F, Kim K, Abbott RM, Cotton M, Levy A, Marchetto P, Ochoa K, Jackson SM, Gillam B, Chen W, Yan L, Higginbotham J, Cardenas M, Waligorski J, Applebaum E, Phelps L, Falcone J, Kanchi K, Thane T, Scimone A, Thane N, Henke J, Wang T, Ruppert J, Shah N, Rotter K, Hodges J, Ingenthron E, Cordes M, Kohlberg S, Sgro J, Delgado B, Mead K, Chinwalla A, Leonard S, Crouse K, Collura K, Kudrna D, Currie J, He R, Angelova A, Rajasekar S, Mueller T, Lomeli R, Scara G, Ko A, Delaney K, Wissotski M, Lopez G, Campos D, Braidotti M, Ashley E, Golser W, Kim H, Lee S, Lin J, Dujmic Z, Kim W, Talag J, Zuccolo A, Fan C, Sebastian A, Kramer M, Spiegel L, Nascimento L, Zutavern T, Miller B, Ambroise C, Muller S, Spooner W, Narechania A, Ren L, Wei S, Kumari S, Faga B, Levy MJ, McMahan L, Van Buren P, Vaughn MW, Ying K, Yeh CT, Emrich SJ, Jia Y, Kalyanaraman A, Hsia AP, Barbazuk WB, Baucom RS, Brutnell TP, Carpita NC, Chaparro C, Chia JM, Deragon JM, Estill JC, Fu Y, Jeddeloh JA, Han Y, Lee H, Li P, Lisch DR, Liu S, Liu Z, Nagel DH, McCann MC, SanMiguel P, Myers AM, Nettleton D, Nguyen J, Penning BW, Ponnala L, Schneider KL, Schwartz DC, Sharma A, Soderlund C, Springer NM, Sun Q, Wang H, Waterman M, Westerman R, Wolfgruber TK, Yang L, Yu Y, Zhang L, Zhou S, Zhu Q, Bennetzen JL, Dawe RK, Jiang J, Jiang N, Presting GG, Wessler SR, Aluru S, Martienssen RA, Clifton SW, McCombie WR, Wing RA, Wilson RK (2009) The B73 maize genome: complexity, diversity, and dynamics. Science 326:1112-1115

Schulte D, Ariyadasa R, Shi B, Fleury D, Saski C, Atkins M, de Jong P, Wu CC, Graner A, Langridge P, Stein N (2011) BAC library resources for map-based cloning and physical map construction in barley (Hordeum vulgare L.). BMC Genomics 12(1):247

Schwab W (2003) Metabolome diversity: too few genes, too many metabolites? Phytochemistry 62:837-849

Seebauer JR, Moose SP, Fabbri BJ, Crossland LD, Below FE (2004) Amino acid metabolism in maize earshoots. Implications for assimilate preconditioning and nitrogen signaling. Plant Physiol 136:4326-4334

Seiler C, Harshavardhan VT, Rajesh K, Reddy PS, Strickert M, Rolletschek H, Scholz U, Wobus U, Sreenivasulu N (2011) ABA biosynthesis and degradation contributing to ABA homeostasis during barley seed development under control and terminal drought-stress conditions. J Exp Bot 62:2615-2632 
Seki M, Ishida J, Narusaka M, Fujita M, Nanjo T, Umezawa T, Kamiya A, Nakajima M, Enju A, Sakurai T, Satou M, Akiyama K, Yamaguchi-Shinozaki K, Carninci P, Kawai J, Hayashizaki Y, Shinozaki K (2002a) Monitoring the expression pattern of around 7,000 Arabidopsis genes under ABA treatments using a full-length cDNA microarray. Funct Integr Genomics 2:282-291

Seki M, Narusaka M, Abe H, Kasuga M, Yamaguchi-Shinozaki K, Carninci P, Hayashizaki Y, Shinozaki K (2001) Monitoring the expression pattern of 1,300 Arabidopsis genes under drought and cold stresses by using a full-length cDNA microarray. Plant Cell 13:61-72

Seki M, Narusaka M, Ishida J, Nanjo T, Fujita M, Oono Y, Kamiya A, Nakajima M, Enju A, Sakurai T, Satou M, Akiyama K, Taji T, Yamaguchi-Shinozaki K, Carninci P, Kawai J, Hayashizaki Y, Shinozaki K (2002b) Monitoring the expression profiles of 7,000 Arabidopsis genes under drought, cold and high-salinity stresses using a full-length cDNA microarray. Plant J: Cell Mol Biol 31:279-292

Shingaki-Wells RN, Huang SB, Taylor NL, Carroll AJ, Zhou WX, Millar AH (2011) Differential molecular responses of rice and wheat coleoptiles to anoxia reveal novel metabolic adaptations in amino acid metabolism for tissue tolerance. Plant Physiol 156:1706-1724

Shulaev V, Cortes D, Miller G, Mittler R (2008) Metabolomics for plant stress response. Physiol Plant 132:199-208

Smit B, Ludlow L, Brklacich M (1988) Implications of a global climatic warming for agriculture: a review and appraisal. J Environ Qual 17:519-527

Sreenivasulu N, Altschmied L, Radchuk V, Gubatz S, Wobus U, Weschke W (2004a) Transcript profiles and deduced changes of metabolic pathways in maternal and filial tissues of developing barley grains. Plant J: Cell Mol Biol 37:539-553

Sreenivasulu N, Miranda M, Prakash HS, Wobus U, Weschke W (2004b) Transcriptome changes in foxtail millet genotypes at high salinity: Identification and characterization of a PHGPX gene specifically up-regulated by $\mathrm{NaCl}$ in a salt-tolerant line. J Plant Physiol 161:467-477

Sreenivasulu N, Radchuk V, Strickert M, Miersch O, Weschke W, Wobus U (2006) Gene expression patterns reveal tissue-specific signaling networks controlling programmed cell death and ABA- regulated maturation in developing barley seeds. Plant J: Cell Mol Biol 47:310-327

Sreenivasulu N, Schnurbusch T (2012) A genetic playground for enhancing grain number in cereals. Trends Plant Sci 17:91-101

Sreenivasulu N, Sopory SK, Kavi Kishor PB (2007) Deciphering the regulatory mechanisms of abiotic stress tolerance in plants by genomic approaches. Gene 388:1-13

Sreenivasulu N, Graner A, Wobus U (2008a) Barley genomics: an overview. Int J Plant Genomics 2008:486258

Sreenivasulu N, Usadel B, Winter A, Radchuk V, Scholz U, Stein N, Weschke W, Strickert M, Close TJ, Stitt M, Graner A, Wobus U (2008b) Barley grain maturation and germination: metabolic pathway and regulatory network commonalities and differences highlighted by new MapMan/PageMan profiling tools. Plant Physiol 146:1738-1758

Sreenivasulu N, Sunkar R, Wobus U, Strickert M (2010) Array platforms and bioinformatics tools for the analysis of plant transcriptome in response to abiotic stress. Methods Mol Biol 639:71-93

Sreenivasulu N, Harshavardhan VT, Govind G, Seiler C, Kohli A (2012) Contrapuntal role of ABA: does it mediate stress tolerance or plant growth retardation under long-term drought stress? Gene 125:625-645

Styczynski MP, Stephanopoulos G (2005) Overview of computational methods for the inference of gene regulatory networks. Comput Chem Eng 29:519-534

Swarbreck D, Wilks C, Lamesch P, Berardini TZ, Garcia-Hernandez M, Foerster H, Li D, Meyer T, Muller R, Ploetz L, Radenbaugh A, Singh S, Swing V, Tissier C, Zhang P, Huala E (2008) The Arabidopsis information resource (TAIR): gene structure and function annotation. Nucleic Acid Res 36:D1009-D1014

Sweetlove LJ, Fell D, Fernie AR (2008) Getting to grips with the plant metabolic network. Biochem J 409:27-41 
Szekely G, Abraham E, Cseplo A, Rigo G, Zsigmond L, Csiszar J, Ayaydin F, Strizhov N, Jasik J, Schmelzer E, Koncz C, Szabados L (2008) Duplicated P5CS genes of Arabidopsis play distinct roles in stress regulation and developmental control of proline biosynthesis. Plant J: Cell Mol Biol 53:11-28

Takahashi S, Seki M, Ishida J, Satou M, Sakurai T, Narusaka M, Kamiya A, Nakajima M, Enju A, Akiyama K, Yamaguchi-Shinozaki K, Shinozaki K (2004) Monitoring the expression profiles of genes induced by hyperosmotic, high salinity, and oxidative stress and abscisic acid treatment in Arabidopsis cell culture using a full-length cDNA microarray. Plant Mol Biol 56:29-55

Tanaka T, Antonio BA, Kikuchi S, Matsumoto T, Nagamura Y, Numa H, Sakai H, Wu J, Itoh T, Sasaki T, Aono R, Fujii Y, Habara T, Harada E, Kanno M, Kawahara Y, Kawashima H, Kubooka H, Matsuya A, Nakaoka H, Saichi N, Sanbonmatsu R, Sato Y, Shinso Y, Suzuki M, Takeda JI, Tanino M, Todokoro F, Yamaguchi K, Yamamoto N, Yamasaki C, Imanishi T, Okido T, Tada M, Ikeo K, Tateno Y, Gojobori T, Lin YC, Wei FJ, Hsing YI, Zhao Q, Han B, Kramer MR, McCombie RW, Lonsdale D, O’Donovan CC, Whitfield EJ, Apweiler R, Koyanagi KO, Khurana JP, Raghuvanshi S, Singh NK, Tyagi AK, Haberer G, Fujisawa M, Hosokawa S, Ito Y, Ikawa H, Shibata M, Yamamoto M, Bruskiewich RM, Hoen DR, Bureau TE, Namiki N, Ohyanagi H, Sakai Y, Nobushima S, Sakata K, Barrero RA, Sato Y, Souvorov A, Smith-White B, Tatusova T, An S, An G, OOta S, Fuks G, Messing J, Christie KR, Lieberherr D, Kim H, Zuccolo A, Wing RA, Nobuta K, Green PJ, Lu C, Meyers BC, Chaparro C, Piegu B, Panaud O, Echeverria M (2008) The rice annotation project database (RAP-DB): 2008 update. Nucleic Acid Res 36:D1028-D1033

Thimm O, Essigmann B, Kloska S, Altmann T, Buckhout TJ (2001) Response of Arabidopsis to iron deficiency stress as revealed by microarray analysis. Plant Physiol 127:1030-1043

Thole V, Worland B, Wright J, Bevan MW, Vain P (2010) Distribution and characterization of more than 1000 T-DNA tags in the genome of Brachypodium distachyon community standard line Bd21. Plant Biotechnol J 8:734-747

Umezawa T, Fujita M, Fujita Y, Yamaguchi-Shinozaki K, Shinozaki K (2006) Engineering drought tolerance in plants: discovering and tailoring genes to unlock the future. Curr Opin Biotech 17:113-122

Urano K, Maruyama K, Ogata Y, Morishita Y, Takeda M, Sakurai N, Suzuki H, Saito K, Shibata D, Kobayashi M, Yamaguchi-Shinozaki K, Shinozaki K (2009) Characterization of the ABA-regulated global responses to dehydration in Arabidopsis by metabolomics. Plant J: Cell Mol Biol 57:1065-1078

Usadel B, Blasing OE, Gibon Y, Poree F, Hohne M, Gunter M, Trethewey R, Kamlage B, Poorter $\mathrm{H}$, Stitt M (2008) Multilevel genomic analysis of the response of transcripts, enzyme activities and metabolites in Arabidopsis rosettes to a progressive decrease of temperature in the non-freezing range. Plant Cell Environ 31:518-547

Vain P, Worland B, Thole V, McKenzie N, Alves SC, Opanowicz M, Fish LJ, Bevan MW, Snape JW (2008) Agrobacterium-mediated transformation of the temperate grass Brachypodium distachyon (genotype Bd21) for T-DNA insertional mutagenesis. Plant Biotechnol J 6:236-245

Van Baarlen P, Van Esse HP, Siezen RJ, Thomma BPHJ (2008) Challenges in plant cellular pathway reconstruction based on gene expression profiling. Trends Plant Sci 13:44-50

van Dijken AJH, Schluepmann H, Smeekens SCM (2004) Arabidopsis trehalose-6-phosphate synthase 1 is essential for normal vegetative growth and transition to flowering. Plant Physiol 135:969-977

Vensel WH, Tanaka CK, Cai N, Wong JH, Buchanan BB, Hurkman WJ (2005) Developmental changes in the metabolic protein profiles of wheat endosperm. Proteomics 5:1594-1611

Verpoorte R, Memelink J (2002) Engineering secondary metabolite production in plants. Curr Opin Biotech 13:181-187

Vij S, Tyagi AK (2007) Emerging trends in the functional genomics of the abiotic stress response in crop plants. Plant Biotechnol J 5:361-380

Vinocur B, Altman A (2005) Recent advances in engineering plant tolerance to abiotic stress: achievements and limitations. Curr Opin Biotech 16:123-132 
Vlad MO, Arkin A, Ross J (2004) Response experiments for nonlinear systems with application to reaction kinetics and genetics. Proc Natl Acad Sci USA 101:7223-7228

Vogel J, Hill T (2008) High-efficiency Agrobacterium-mediated transformation of Brachypodium distachyon inbred line Bd21-3. Plant Cell Rep 27:471-478

Vogel JP, Tuna M, Budak H, Huo N, Gu YQ, Steinwand MA (2009) Development of SSR markers and analysis of diversity in Turkish populations of Brachypodium distachyon. BMC Plant Biol 9:88

Walia H, Wilson C, Condamine P, Ismail AM, Xu J, Cui X, Close TJ (2007) Array-based genotyping and expression analysis of barley cv. Maythorpe and Golden Promise. BMC genomics $8: 87$

Walia H, Wilson C, Wahid A, Condamine P, Cui X, Close TJ (2006) Expression analysis of barley (Hordeum vulgare L.) during salinity stress. Funct Integr Genomics 6:143-156

Wan JX, Griffiths R, Ying JF, McCourt P, Huang YF (2009) Development of drought-tolerant canola (Brassica napus L.) through genetic modulation of ABA-mediated stomatal responses. Crop Sci 49:1539-1554

Wang H, Schauer N, Usadel B, Frasse P, Zouine M, Hernould M, Latche A, Pech JC, Fernie AR, Bouzayen M (2009) Regulatory features underlying pollination-dependent and -independent tomato fruit set revealed by transcript and primary metabolite profiling. Plant Cell 21:1428-1452

Wang W, Vinocur B, Altman A (2003) Plant responses to drought, salinity and extreme temperatures: towards genetic engineering for stress tolerance. Planta 218:1-14

Wanjugi H, Coleman-Derr D, Huo N, Kianian SF, Luo MC, Wu J, Anderson O, Gu YQ (2009) Rapid development of PCR-based genome-specific repetitive DNA junction markers in wheat. Genome 52:576-587 National Research Council Canada, Conseil National de Recherches Canada

Wasinger VC, Cordwell SJ, Cerpa-Poljak A, Yan JX, Gooley AA, Wilkins MR, Duncan MW, Harris R, Williams KL, Humphery-Smith I (1995) Progress with gene-product mapping of the Mollicutes: Mycoplasma genitalium. Electrophoresis 16:1090-1094

Wei F, Zhang J, Zhou S, He R, Schaeffer M, Collura K, Kudrna D, Faga BP, Wissotski M, Golser W, Rock SM, Graves TA, Fulton RS, Coe E, Schnable PS, Schwartz DC, Ware D, Clifton SW, Wilson RK, Wing RA (2009) The physical and genetic framework of the maize B73 genome. PLoS Genet 5:e1000715

Weigel D, Ahn JH, Blazquez MA, Borevitz JO, Christensen SK, Fankhauser C, Ferrandiz C, Kardailsky I, Malancharuvil EJ, Neff MM, Nguyen JT, Sato S, Wang ZY, Xia YJ, Dixon RA, Harrison MJ, Lamb CJ, Yanofsky MF, Chory J (2000) Activation tagging in Arabidopsis. Plant Physiol 122:1003-1013

Westerhoff HV, Palsson BO (2004) The evolution of molecular biology into systems biology. Nat Biotechnol 22:1249-1252

Wicker T, Mayer KFX, Gundlach H, Martis M, Steuernagel B, Scholz U, Simkova H, Kubalakova M, Choulet F, Taudien S, Platzer M, Feuillet C, Fahima T, Budak H, Dolezel J, Keller B, Stein N (2011) Frequent gene movement and pseudogene evolution is common to the large and complex genomes of wheat, barley, and their relatives. Plant Cell 23:1706-1718

Wiechert W, Mollney M, Petersen S, de Graaf AA (2001) A universal framework for 13C metabolic flux analysis. Metab Eng 3:265-283

Williams TC, Poolman MG, Howden AJ, Schwarzlander M, Fell DA, Ratcliffe RG, Sweetlove LJ (2010) A genome-scale metabolic model accurately predicts fluxes in central carbon metabolism under stress conditions. Plant Physiol 154:311-323

Wittmann C, Kiefer P, Zelder O (2004) Metabolic fluxes in Corynebacterium glutamicum during lysine production with sucrose as carbon source. Appl Environ Microbiol 70:7277-7287

Worch S, Rajesh K, Harshavardhan VT, Pietsch C, Korzun V, Kuntze L, Borner A, Wobus U, Roder MS, Sreenivasulu N (2011) Haplotyping, linkage mapping and expression analysis of barley genes regulated by terminal drought stress influencing seed quality. BMC Plant Biol 11:1 
Xu J, Tian J, Belanger FC, Huang B (2007) Identification and characterization of an expansin gene AsEXP1 associated with heat tolerance in C3 Agrostis grass species. J Exp Bot 58:3789-3796

Xue GP, McIntyre CL, Chapman S, Bower NI, Way H, Reverter A, Clarke B, Shorter R (2006) Differential gene expression of wheat progeny with contrasting levels of transpiration efficiency. Plant Mol Biol 61:863-881

Yamaguchi T, Nakayama K, Hayashi T, Yazaki J, Kishimoto N, Kikuchi S, Koike S (2004) cDNA microarray analysis of rice anther genes under chilling stress at the microsporogenesis stage revealed two genes with DNA transposon Castaway in the 5'-flanking region. Biosci Biotech Bioch 68:1315-1323

Yamakawa H, Hakata M (2010) Atlas of rice grain filling-related metabolism under high temperature: joint analysis of metabolome and transcriptome demonstrated inhibition of starch accumulation and induction of amino acid accumulation. Plant Cell Physiol 51:795-809

Yang S, Vanderbeld B, Wan J, Huang Y (2010) Narrowing down the targets: towards successful genetic engineering of drought-tolerant crops. Mol Plant 3:469-490

Youens-Clark K, Buckler E, Casstevens T, Chen C, DeClerck G, Derwent P, Dharmawardhana P, Jaiswal P, Kersey P, Karthikeyan AS, Lu J, McCouch SR, Ren LY, Spooner W, Stein JC, Thomason J, Wei S, Ware D (2011) Gramene database in 2010: updates and extensions. Nucleic Acids Res 39:D1085-D1094

Yu J, Hu SN, Wang J, Wong GKS, Li SG, Liu B, Deng YJ, Dai L, Zhou Y, Zhang XQ, Cao ML, Liu J, Sun JD, Tang JB, Chen YJ, Huang XB, Lin W, Ye C, Tong W, Cong LJ, Geng JN, Han YJ, Li L, Li W, Hu GQ, Huang XG, Li WJ, Li J, Liu ZW, Li L, Liu JP, Qi QH, Liu JS, Li L, Li T, Wang XG, Lu H, Wu TT, Zhu M, Ni PX, Han H, Dong W, Ren XY, Feng XL, Cui P, Li XR, Wang H, Xu X, Zhai WX, Xu Z, Zhang JS, He SJ, Zhang JG, Xu JC, Zhang KL, Zheng XW, Dong JH, Zeng WY, Tao L, Ye J, Tan J, Ren XD, Chen XW, He J, Liu DF, Tian W, Tian CG, Xia HG, Bao QY, Li G, Gao H, Cao T, Wang J, Zhao WM, Li P, Chen W, Wang XD, Zhang Y, Hu JF, Wang J, Liu S, Yang J, Zhang GY, Xiong YQ, Li ZJ, Mao L, Zhou CS, Zhu Z, Chen RS, Hao BL, Zheng WM, Chen SY, Guo W, Li GJ, Liu SQ, Tao M, Wang J, Zhu LH, Yuan LP, Yang HM (2002) A draft sequence of the rice genome (Oryza sativa L. ssp indica). Science 296:79-92

Zamboni N, Sauer U (2004) Model-independent fluxome profiling from 2H and 13C experiments for metabolic variant discrimination. Genome Biol 5:R99

Zeller G, Henz SR, Widmer CK, Sachsenberg T, Ratsch G, Weigel D, Laubinger S (2009) Stressinduced changes in the Arabidopsis thaliana transcriptome analyzed using whole-genome tiling arrays. Plant J: Cell Mol Biol 58:1068-1082

Zhang HX, Lian CL, Shen ZG (2009) Proteomic identification of small, copper-responsive proteins in germinating embryos of Oryza sativa. Ann Bot 103:923-930

Zhang YX, Wu RH, Qin GJ, Chen ZL, Gu HY, Qu LJ (2011) Over-expression of WOX1 leads to defects in meristem development and polyamine homeostasis in Arabidopsis. J Integr Plant Biol 53:493-506

Zhou S, Wei F, Nguyen J, Bechner M, Potamousis K, Goldstein S, Pape L, Mehan MR, Churas C, Pasternak S, Forrest DK, Wise R, Ware D, Wing RA, Waterman MS, Livny M, Schwartz DC (2009) A single molecule scaffold for the maize genome. PLoS Genet 5:e1000711

Zhu H, Bilgin M, Snyder M (2003) Proteomics. Annu Rev Biochem 72:783-812 